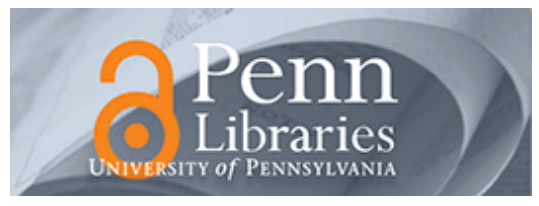

University of Pennsylvania

ScholarlyCommons

Management Papers

Wharton Faculty Research

8-2005

\title{
Organizing Venture Capital: The Rise and Demise of American Research \& Development Corporation, 1946-1973
}

David H. Hsu

University of Pennsylvania

Martin Kenney

Follow this and additional works at: https://repository.upenn.edu/mgmt_papers

Part of the Business Administration, Management, and Operations Commons

\section{Recommended Citation}

Hsu, D. H., \& Kenney, M. (2005). Organizing Venture Capital: The Rise and Demise of American Research \& Development Corporation, 1946-1973. Industrial and Corporate Change, 14 (4), 579-616.

http://dx.doi.org/10.1093/icc/dth064

This paper is posted at ScholarlyCommons. https://repository.upenn.edu/mgmt_papers/87

For more information, please contact repository@pobox.upenn.edu. 


\title{
Organizing Venture Capital: The Rise and Demise of American Research \& Development Corporation, 1946-1973
}

\begin{abstract}
While venture capital (VC) has become an important element of the twentiethcentury US innovation system, few studies have systematically examined the origins and evolution of this financial institution. We take a step in this direction by analyzing the evolution of the early and influential VC firm, American Research \& Development Corporation (ARD), in the period that it was independent from 1946 to 1973 . We place the creation and subsequent evolution of ARD within its historical context and show how it was an innovation by Boston-area civic elites. Using new historical data, we examine the evolution of ARD's practices over time. We argue that ARD's funding model constrained its functioning as a venture capital firm and contributed to its demise. ARD was a pioneering organization whose business model ultimately failed as a newer organizational model, the limited partnership, was created and had a better fit with the business environment. Nevertheless, ARD has had a lasting imprint on the practice of modern venture capital.
\end{abstract}

\section{Keywords}

venture capital, entrepreneurship, organizational evolution, business history

\section{Disciplines}

Business Administration, Management, and Operations 


\title{
Organizing Venture Capital: The Rise and Demise of American Research \& Development Corporation, 1946-1973*
}

\author{
by \\ David H. Hsu \\ The Wharton School \\ University of Pennsylvania \\ 2000 Steinberg-Dietrich Hall, \\ Philadelphia, PA 19104 \\ dhsu@wharton.upenn.edu \\ $\&$ \\ Martin Kenney \\ Department of Human and Community Development \\ University of California, Davis \\ Davis, CA 95616 \\ mfkenney@ucdavis.edu
}

Working Paper 163

December 2004

CCopyright 2004 by the authors

* Permission to access and quote from the personal papers of Georges Doriot was kindly granted by Richard J. Testa, Esq. We thank Richard Florida, David Kirsch, Dave Mowery, Dick Nelson, Hayagreeva Rao, Ed Roberts, and F.M. Scherer for helpful comments and discussions. David Hsu acknowledges funding from the Mack Center for Technological Innovation at Wharton and the MIT Entrepreneurship Center. Martin Kenney acknowledges funding from the Alfred P. Sloan Foundation. 


\author{
Organizing Venture Capital: The Rise and Demise of \\ American Research \& Development Corporation, 1946-1973
}

\begin{abstract}
While venture capital (VC) has become an important element of the $20^{\text {th }}$ century U.S. innovation system, few studies have systematically examined the origins and evolution of this financial institution. We take a step in this direction by analyzing the evolution of the early and influential VC firm, American Research \& Development Corporation (ARD), in the period that it was independent from 1946-1973. We place the creation and subsequent evolution of ARD within its historical context and show how it was an innovation by Boston-area civic elites. Using new historical data, we examine the evolution of ARD's practices over time. We argue that ARD's funding model constrained its functioning as a venture capital firm and contributed to its demise. ARD was a pioneering organization whose business model ultimately failed as a newer organizational model, the limited partnership, was created and had a better fit with the business environment. Nevertheless, ARD has had a lasting imprint on the practice of modern venture capital.
\end{abstract}

Keywords: Venture capital, entrepreneurship, organizational evolution, business history. 
The 1929 stock market collapse was reflected and magnified in the bankruptcies of enormous numbers of smaller firms as the financial system ground to a halt. The ensuing depression galvanized a debate about the merits and directions of the U.S. political economy. This paper explores what at the time was a minor, almost footnote-size, response to this overall crisis, the creation of the venture capital firm. This remarkable experiment at economic institution building has, in the intervening six decades, created an institutional form that today is deemed by many as a critical component of the U.S. national innovation system. It has also become an asset category so widely accepted that large U.S. pension funds and institutional funds allocate a specific percentage of their total funds to venture capital firms.

Venture capital as a financing institution was not a natural evolution from a set of informal investors who gradually formalized their practice; rather it was a conscious creation by East Coast and especially New England business and civic leaders responding to what they saw as a social and economic need. These leaders were concerned about the future of New England and the ability of the U.S. financial system to recover from the Great Depression and the effect of the New Deal reforms. They fervently believed that small innovative new firms or smaller firms seeking to upgrade and expand their operations could provide a source of significant capital gains and that their growth could contribute to employment growth in New England and the U.S. For them the fruits of scientific and technological advances could form the basis of new firms that would result in the development of entirely new industries, but that there was a shortage of dedicated early stage capital with professional involvement to accomplish this. The dedicated venture capital firm was the result of a conscious institutional innovation effort prior to World War Two but realized only after the war. This paper examines the history and evolution of the first independent venture capital organization, American Research and Development (ARD), which was incorporated in $1946 .^{1}$

ARD's promoters believed that two developments had combined to cut-off the supply of risk capital to new firms. The first development was the implementation of New Deal financial system

\footnotetext{
${ }^{1}$ The two seminal works on ARD are Liles (1977) and Reiner (1989). For the role of MIT in the formation of ARD see, also, Etzkowitz (2002).
} 
reforms that dramatically increased income taxes and reorganized the financial system in a way that dampened private investment in high-risk ventures. The second development was the rise of investment trusts (progenitors of mutual funds) that provided safe, conservative investments that may have crowded out higher risk investments. The investment trusts and life insurance firms were garnering an ever greater portion of societal savings, but were reluctant to invest in high-risk small firms. For ARD's founders and promoters, venture capital was meant to operate as a mechanism for recycling a certain portion of the societal savings into innovative new firms meant to discover what Schumpeter termed "New Economic Spaces".

In contrast to venture capital firms formed contemporaneously by wealthy families such as the Rockefellers, Whitneys, and Payson and Trask, ARD was the only non-family venture capital firmmeaning it had to raise capital from other sources. ARD was also an experiment to see if a new organizational form created by the private sector could profitably discharge the function of funding the Schumpeterian process of creative destruction. It was an experiment that had four goals: (1) to nurture new firms and assist existing firms in upgrading their technology or adding new product lines, (2) to encourage the commercialization of technological innovations, (3) to contribute to an economic revival in New England, and (4) to assist in the diffusion of privately funded venture capital as an institution. To accomplish these goals, its originators believed that ARD would have to be profitable otherwise it would not become a model for other firms. We evaluate the ARD experiment on the basis of these goals, as well as on one further dimension: whether the publicly-traded investment company organizational form chosen by ARD's sponsors was a successful business model.

The paper begins with a discussion of the regional and national context within which ARD was conceived and established. The second section describes the efforts by New England civic leaders to establish an organization specializing in the provision of venture capital. The third section examines the search for the right organizational form for venture capital. The fourth section describes the creation of ARD. The fifth section examines ARD's investments in terms of the four goals set out for it by its founders. The next section describes the internal difficulties and contradictions with which ARD had to 
cope and the growth of competitors able to take advantage of these difficulties. The conclusion reflects on the success ARD had in meeting the goals of its founders, and the reasons for its ultimate decline.

\section{The Regional and National Context}

The concept of a separate organizational form dedicated to funding new firms and providing after-investment support for new firms first surfaced in New England during the late 1920s as a response to the decline of the New England local garment and textile industry. From the end of World War One onward, New England had experienced a massive deindustrialization. For example, employment in cotton manufacturing in Massachusetts peaked at 124,000 employees in 1919 and fell to 71,000 workers in 1929 prior to the Great Depression, and this trend was mirrored in other garment and textile-related sectors. $^{2}$ The 1930 s sealed the fate of the industry as it declined to less than 30,000 by 1940 . This decline was all the more striking as the neighboring Midwestern states benefited from the creation and expansion of entirely new industries such as automobiles, radios, and other consumer durables.

The Great Depression dramatically heightened concern about the direction of the U.S. economy due to the lost confidence in American economic institutions. For example, from 1929 to 1939, the total number of persons employed in manufacturing dropped 13.5 percent (Kaplan 1948: 44), the number of manufacturing establishments decreased 10.9 percent while independent manufacturers fell 18.1 percent, and the number of wage earners in independent manufacturers plummeted by 23.3 percent. Overall, manufacturing exhibited a movement towards larger industrial units as smaller firms and factories failed (Kaplan 1948: 38). In the financial sector the story was similar as two thousand investment firms and seven thousand banks, the vast majority being smaller local firms, failed (Chernow 1990). The financial sector difficulties had a severe impact on the ability of smaller firms to secure long-term loans and especially equity capital. In a nutshell, Wall Street's pain was amplified into Main Street's agony.

\footnotetext{
${ }^{2}$ While there have been numerous explanations advanced for this decline (Lazonick 1991), for the participants at the time, it appeared inexorable.
} 
The financial and tax reforms implemented in the New Deal further disrupted the traditional pathways for the provision of capital to new firms. For example, Congressional hearings after the stock market crash showed that investment bankers were deliberately concealing information from the public at the time of initial public stock offerings (Pontecorvo 1958; Schlesinger 1959). In response, in 1934 the Securities and Exchange Commission was created to curtail securities abuses and require greater disclosure for firms wishing to offer stock to the public. In 1933, the Glass-Steagall Banking Act fundamentally changed the operation of banks by forcing them to sever their commercial bank function of taking deposits and making loans from investment banking activities and the ownership of sizable equity positions in industrial firms (Chernow 1990: 360-363). ${ }^{3}$ A progressive income tax that many wealthy individuals denounced as confiscatory was introduced. The wealthy claimed they no longer had sufficient excess capital to invest in small firms, and any capital gains they received from such risky investment would be lost due to high taxes. ${ }^{4}$ Whatever the merits of these arguments, the channels for allocating funds to small firms were disrupted (Weissman 1945: 41).

Combined with this disruption was a concern by some observers particularly those in New England that investment trusts were attracting funds into relatively risk-free investments and thereby limiting the funds available for more risky investments. Interestingly, this sentiment was not confined to businesspersons and academics. Merrill Griswold, then president of one of the largest investment trusts, the Massachusetts Investment Trust, believed that the growing tendency among Americans to invest in investment trusts managed by professional managers was reducing the "idle" capital available for investment in high-risk small businesses. In Keynesian terms, the 'animal spirits' that motivated capitalists were being replaced by safer, if less potentially profitable investments. This short-circuited the

\footnotetext{
${ }^{3}$ For a brief in opposition to the separation of investment banking and commercial banking, see Osterweis 1932.

${ }^{4}$ For example, in a 1939 speech to the Modern Pioneers Dinner in Rochester, New York, Karl Compton stated "taxation for the purpose of redistribution of wealth and the support of less privileged groups will fail its objective whenever it reaches such a point as to inhibit the development of new industrial or business enterprises which have in them the possibility of providing new employment and new wealth for distribution (Compton 1940: 323).
} 
supply of capital to small firms, and motivated Griswold to support the creation of a separate organizational form dedicated to providing financial and other assistance to small businesses.

The ramifications of the Great Depression went much further. Big business was blamed for the economic catastrophe (Leuchtenberg 1958; Mitchell 1947; Skocpol 1995). Out of this distrust came two political movements that had a profound influence on the proponents of venture capital. The first movement was motivated by a belief that small business required government support. The second movement blamed technology, particularly automation, for the unemployment problem and agitated for a halt to technological progress (Hart 1998; Bix 2000). These two separate debates merged in the thinking of a number of leading New England civic leaders who came to believe that the creation of small firms to exploit new technologies could contribute to the solution of the U.S. economic crisis.

The call for support of small business led to the question of what types of small businesses should be targeted. The largest group favored support for all manner of small firms. A smaller, but more elite, group located in New England that included Karl T. Compton the president of MIT; Ralph Flanders, a prominent New England businessperson; Lincoln Filene, a prominent New England businessperson, Merrill Griswold, the president of the largest open-ended investment trust in New England, Massachusetts Investment Trust, among others proposed developing private sector initiatives to support small businesses established to commercialize new products, processes, or seeking expansion capital. This group was concentrated in New England and advocated a private sector solution whereby private entities would provide funds to firms that might create new industries. For them the current problem was, as Ralph Flanders (1945: 2608) wrote, that large firms were willing to invest in research of significance to their operations, but they did not invest in creating new industries, leading to "heavy brakes on the development of new industry." This, he thought, was "not in the public interest." Here was an appropriation of populist rhetoric that was repackaged into the recommendation that research should contribute to the creation of new firms and industries.

The anti-technology movement had little success and the technological "miracles" such as the atomic bomb, radar, and penicillin that were demonstrated during World War Two ensured that the 
proponents of encouraging continuing technological change (such as Karl Compton) won out. Moreover, these successes convinced an increasing number that technological developments could lead to the creation of new firms and industries. In November 1944, with war ending, U.S. President Franklin Roosevelt asked Dr. Vannevar Bush, an MIT professor and then the director of The Office of Scientific Research and Development, which was responsible for coordinating scientific research for the war effort, for recommendations on peacetime science policy. In addition to his civil service experience, Bush also was familiar with private initiatives to commercialize technology, having founded Raytheon Corporation in 1922. Bush's resulting report entitled, Science: The Endless Frontier, called for establishing a new federal government agency, a "National Research Foundation" to promote basic research that contributed to economic progress:

"In 1939 millions of people were employed in industries which did not even exist at the close of the last war-radio, air conditioning, rayon and other synthetic fibers, and plastics are examples of the products of these industries. But these things do not mark the end of progress - they are but the beginning if we make full use of our scientific resources. New manufacturing industries can be started and many older industries greatly strengthened and expanded if we continue to study nature's laws and apply new knowledge to practical purposes. ... But to achieve these objectives - to secure a high level of employment, to maintain a position of world leadership - the flow of new scientific knowledge must be both continuous and substantial." (Bush, 1945, p. 10-11).

Vannevar Bush was asserting the importance of scientific research to American business. What is of great significance for this paper is his mention of new industries, something that resonated with his firsthand experience at Raytheon and the discussions underway among his ex-colleagues at MIT (Scott 1974). For Bush and Compton, it was an article of faith that new science and technological developments would inevitably result in new firms and industries and, as a result, new employment (Compton 1934). These would provide the impetus to prevent a post-war return of the Depression. However, for these new firms to come into being, capital would be required. 


\section{New England Invents Venture Capital $^{5}$}

The idea of venture capital did not spring forth from New England civic leaders fully formed. In 1911, responding to concerns about the New England economy, the Boston Chamber of Commerce established an industrial development corporation. However, its results were unsatisfactory and it was discontinued in 1914 (Kaplan 1948: 156-180). This did not deter Boston civic leaders from searching for mechanisms to revitalize the New England economy. In 1926 Lincoln Filene, the Boston department store magnate, encouraged local politicians, business persons, and educators to form the New England Council (NEC) with the express goal of improving the region's worsening economic conditions due to the terminal decline of its textile and garment industries (New England Council 1929).

In its 1929 report, the NEC advocated both the attraction of branch plants and the development of new undertakings and believed that "the growth of industry in New England can best be promoted by local enterprises financed by local capital" (NEC 1929: 13). Contemporaneously, a committee of local bankers working with the NEC studied the possibility of existing financial institutions extending their mandate to providing financial support for local small firms. Their report identified a need for equity or long-term capital to support small businesses, but also concluded that the provision of such financing was outside the normal function of banks. They described the difficulty small firms faced succinctly, "it is necessary for the [small] company to go without the needed capital or to sell stock, or to find additional private capital. If it chooses to sell stock, it often pays a prohibitive price for its capital; if it succeeds in interesting private capital, this ordinarily necessitates surrendering control of the business - in many cases into hands less expert in its actual management (quoted in Stoddard 1940: 268)." In response to the perceived need for capital, an effort was made to create an organization expressly to provide capital for innovative small firms, though the onset of the Great Depression truncated that effort.

In 1939 the Council appointed a subcommittee to examine how new products might become the focus for revitalizing the New England economy. The New Products Subcommittee's membership

\footnotetext{
${ }^{5}$ For an excellent discussion of this period from the perspective of MIT, see Etzkowitz 2002.
} 
included Karl Compton, the President of MIT, and General Georges Doriot, a Harvard Business School Professor (Etzkowitz 2002). ${ }^{6}$ Karl Compton was especially eager to have MIT play a central role in a technology-based revitalization stating that, "nowhere in the country [is there] such a concentration of scientific and engineering laboratories and personnel (Compton 1939)." The subcommittee report concluded that the key to resurrecting the New England economy were new firms commercializing new products that might create new industries. By implication, this argued that rather than focusing on aiding existing companies in "sunset" industries such as shoe-making and textiles; it would be better to encourage the formation of new firms in "sunrise" industries, and to assist established firms in upgrading their operations.

The New Products Committee heeded the earlier report on the constraints banks faced and began to think about how to develop an organization for the delivery of venture capital services. They also recognized that any organization seeking to invest in fledgling firms would require a capacity to evaluate them - something that did not exist in most financial organizations. For example, in 1939 the New Products Committee Compton headed concluded that "New England is not hindered by the lack of venture capital [what today is known as "angel" capital]; the need rather is for organization and technique to appraise opportunities for specific enterprises (Cross 1940a)." It was also plain to them that the role of the investor should go beyond evaluating the firm's quality, but also encompass the provision of afterinvestment monitoring and services. Moreover, the venture capital organization was meant to be a profitmaking entity not a charity. The promoters also confronted the knotty problem of raising enough cash to launch the firm and pay for its business professionals. Put differently, they meant to professional the process of investing in fledgling firms. ${ }^{7}$

\footnotetext{
${ }^{6}$ See Etzkowitz (2002) for a detailed discussion of MIT during this period.

${ }^{7}$ The classic citation on this is Max Weber's (1968) work on the rationalization and professionalization of the legal system. The sociology of professions and the process of professionalization is an enormous literature in its own right.
} 


\section{Searching for an Organizational Form}

With the partial economic recovery at the end of the 1930s, the effort to establish an organization to provide investment capital to small firms renewed. The search for capital was not easy because this was the first organization of its type to be formed. It needed to find patient investors willing to tolerate the large number of failures characteristic of small firms and the long gestation periods during which fledgling firms spend more than they earn, all on the promise of large capital gains sometime in the future. They recognized that investors would have to make a leap of faith and so would have to also appeal to civic virtue to convince otherwise rational investors.

A discussion of venture capital in 1939 by the New Products Committee seems, in retrospect, confused as they groped for what a venture capital organization should be doing:

"Funds to provide for further research in the small percentage of cases where competent opinion considers it warranted, for pilot production, for prosecution of patents, and the final commercialization through sale or licensing and, in rare instances, perhaps through the organization of a company, are necessary.

Of the various methods by which new capital might be made available, perhaps the idea of a revolving fund is one that in theory possesses certain advantages. If such a fund could be created, it might, through administration by trustees, be utilized for carrying approved projects through the sequence of research, experimental production and finally, commercialization. It should be considered that this fund offers a source of permanent capital, but that it would be replenished through profits received from license fees or the sale of the product or process outright to an existing manufacturer.

A collateral activity ought, perhaps, to be through the coordination of technical and engineering opinion in various fields competent to pass on the merits of a given proposition. Such a service might further be available to investment banking firms or individuals who are considering the underwriting of, or investing in, new proposition" (Cross 1939).

There were other local experiments. For example, the New England Industrial Development Corporation (NEIDC) was launched in 1941 by a group of wealthy Bostonians with William Stoddard as the president. The modus operandi for the NEIDC was that when it was approached for financial support, it made a preliminary evaluation of the candidate. If the initial evaluation was favorable, the candidate firm was charged for a further investigation. If this investigation was favorable, then a preferred stock investment with a common stock bonus was made (Weissman 1945: 50). Notice that the entrepreneurial 
firm bore the costs of investigation - not an attractive proposition for a cash-strapped start-up. Upon receiving a progress report on the NEIDC in 1940, Compton (1940) concluded that because it would not invest in the development of promising devices, it did not meet the vision of the New Products Committee recommendations and thus left "the basic problem of initiating new projects untouched." There is no record of whether NEIDC was successful, however it was no longer mentioned in later press reports on venture capital.

Other initiatives were launched. For example, in 1946 New Enterprises Inc. was established as a reorganization of a similar group that operated prior to World War Two. It was meant to provide a group of investors with an "engineering survey and confidential report" on candidate firms (Etzkowitz 1993: 344). After receiving this report, the New Enterprises participants then were at liberty to invest, if they wished. In other words, the actual investment decision was not with the organization but with its members. After World War Two, New Enterprises was initially capitalized with $\$ 300,000$ that was meant to fund the final research stages of projects through the pilot plant stage and then list the firm on the stock exchange (Compton 1946). Karl Compton was unwilling to join New Enterprises, but General Georges Doriot did join its board of directors (ARD 1946b). By 1949, New Enterprises had been responsible for only five investments and there is no further record of the firm after 1950 (New England News Letter 1949: 4; Business Week 1946b: 36).

In the early 1940s, the New Products Committee and Karl Compton (1941), in particular, decided the key to encouraging new firm formation was an organization that would employ skilled personnel to evaluate the various opportunities, because there appeared to be sufficient venture capital available. Compton proposed that the New England Industrial Research Foundation be created through a subscription of $\$ 100,000$ from various New England groups. This would form the seed for an organization that would survive on fees for its investigations, reports and services to the new firms that would receive investments (New England Industrial Research Foundation, Inc. 1941). It is not exactly clear why this first vision never was brought to fruition, but ultimately it would not be the configuration 
of the venture capital firm that resulted from the New Products Committee's deliberations, though vestiges of this idea remained in the form of ARD's desire to sell services to its portfolio firms.

Compton worked closely with Ralph Flanders, also a member of the New Products Committee, an industrialist and head of the Federal Reserve Bank of Boston (1944-1946), and Merrill Griswold who strongly supported the development of an organization to support small businesses (Fortune 1945). By the end of World War Two, the proponents had decided that a venture capital organization would not only evaluate and assist fledgling firms, but would also have to invest in the firms. In effect, the idea that a venture capital firm would be the source of capital appears to have derived from the recognition that the critical component was the evaluation, assistance, and monitoring functions. ${ }^{8}$ Thus a venture capital organization required both managerial and investment skills. Even with this understanding and the backing of powerful civic leaders, creating an organization capable of providing such services would be difficult.

\section{Creating American Research and Development Corporation}

Venture capital as a new organizational form was born in 1946, in the belief that research and development, when coupled with professional management, could provide economic growth and capital appreciation. Thus ARD was the crystalization of discussions that had been underway for fifteen years. The prime movers supporting ARD were by Ralph Flanders, then President of the Boston branch of the Federal Reserve and trustee at MIT (and soon thereafter elected as a U.S. senator from Vermont ${ }^{9}$ ), Georges Doriot, a professor of industrial administration at Harvard Business School; Karl Compton; and Merrill Griswold. In 1946 Ralph Flanders summarized the need for ARD as follows:

"As the years go by in our highly industrialized society, the funds available for new enterprise tend to concentrate in fiduciary hands. This in itself is a natural process, but it does make it more and more difficult, as time goes on, to finance new undertakings. The continued maintenance of prosperity and the continued increase in the general standard of

\footnotetext{
${ }^{8}$ The earliest use of the term "venture capital" appears to have been by Lammot DuPont the chairman of Dupont Chemical in its 1938 Annual Report.

${ }^{9}$ It is difficult to speculate to what extent Flanders' election to the U.S. Senate had on VC development, though he did not serve on the Small Business Committee (the Small Business Administration was founded in 1953).
} 
living depend in a large measure in finding financial support for that comparatively small percentage of new ideas and developments, which give promise of expanded production and employment, and an increased standard of living for the American people. We cannot float along indefinitely on the enterprise and vision of preceding generations. To be confident that we are in an expanding, instead of a static or frozen economy, we must have a reasonably high birth rate of new undertakings."

This succinctly summarized the belief that entrepreneurship was vital to the continuing growth of the U.S. economy.

As the first organized venture capital firm, and, more importantly, as the first to raise its funds from institutional investors and the public, ARD's progress was widely reported (Bello 1952; New York Times 1946a). The founders' goals were far greater than simply starting a venture capital firm, they aimed to create a venture capital industry.

ARD was not the only dedicated venture capital organization created in the aftermath of World War Two. A few wealthy East Coast families also established professional venture capital operations (Business Week, 1946a, 1946b, 1946c; Barron's, 1949; Fortune, 1949). The three operations of sustained significance were Rockefeller Brothers Inc. (RBI), J. H. Whitney, and Payson \& Trask (P\&T). The family fund that would prove to be the most significant was Rockefeller Brothers Inc. (New York Times 1946b: 24), which later was reorganized and renamed Venrock. Though it had a professional staff, the funds were collected from family members for each investment (Crisp 1999), and though it was a limited partnership it was completely controlled by the family. In contrast to ARD, many of RBI's investments were in government-related fields where it could rely on the strong family connections in Washington (Lewis 2002).

In terms of long-term significance, RBI would be the most influential. J. H. Whitney was also organized as a partnership and began with $\$ 10$ million invested by J. H. Whitney. The fund was successful almost immediately with an investment in Minute Maid, which had developed a process to produce frozen concentrated orange juice. During this period, Whitney made a wide variety of eclectic investments and, in contrast to RBI, did not appear to be drawn to technology-based investments. The final major early entrant was Payson and Trask (P\&T), which received its capital from Payson, who was 
J. H. Whitney's sister. P\&T did not make technology investments and, though it was moderately successful, became inactive in the 1960s (Stillman 1999). There was a variety of other family investment house, such as T. Mellon \& Sons, the William Burden Company, the Rosenwald's family investment office that intermittently would make venture capital and private equity investments, but were not established for the sole purpose of making venture capital investments. Though significant as familyfunded firms, they could not provide a model for independent venture capitalists that did not have direct access to family funds, though it should be noted that the first independent venture capital limited partnerships raised their funds from families and individuals. Because each of these venture capital firms including ARD had their own niches and many investment opportunities, there was little interfirm rivalry. As an organization with a novel mission, ARD had to repeatedly explain its purpose, since it was always in danger of being unfavorably compared with organizations, such as traditional closed-end investment trusts that appeared to be similar organizationally. To explain ARD to investors, in 1951 Doriot wrote:

"In recent months American Research has been erroneously compared to well-known, long-established investment companies. It should again be emphasized that American Research is a 'venture' or 'risk capital' enterprise. The Corporation does not invest in the ordinary sense. It creates. It risks. Results take more time and the expenses of its operation must be higher, but the potential for ultimate profits is much greater." (ARD Annual Report, 1951).

Whereas most investment trusts were evaluated on quarterly or annual returns, Doriot was suggesting that longer-term criteria be adopted for ARD. He wanted public markets to see ARD as a different class of investment with a different value proposition.

At its core ARD carried an apparent contradiction: it was meant to create the social good of new economic activity, yet it had to be profitable. As Richard B. Cross, the secretary of the New Products Committee (1940b) wrote, "our ideas tend more toward a corporation organized on a business basis which can eventually be self supporting. However, we do believe that the undertaking should be broadly sponsored and not regarded solely as a private, profit-making venture." ARD was meant to be a business proposition and its backers believed that venture capital as an institution could only succeed if it had good economic returns. 
To create any new organizational form, it is necessary to secure the initial resources. In 1943 the New England Council (1943) held a meeting with representatives of different financial institutions to gauge their ability to provide funds for a venture capital organization. Reinforcing the 1929 report by the financial committee, commercial banks, savings banks, and insurance firms stated that they could not provide funds for new enterprises. Representatives from the investment trusts also stated that it would be difficult for them to invest monies directly in small, illiquid firms, because open-end funds were vulnerable to redemption calls that it might be difficult to meet if their capital was tied-up in illiquid venture investments. This was a problem that a closed-end fund did not have because it was traded on the stock market. In a panel organized by the NEC in 1943, William F. Morton a vice president at Boston's State Street Investment Corporation argued that investment trusts did not have research organizations optimized to evaluate and monitor small, high-risk investments (Morton 1943: 6). ${ }^{10}$ At the same meeting, Merrill Griswold (1943: 8) agreed with Morton that while investment trusts were not in a position to invest directly in new enterprises, it would be possible for them to invest in closed-end venture capital investment trusts. The sentiment that the investment trusts should use these closed end vehicles seems to have been rather widely accepted. For example, John Bogle (2001: 451), who would establish the Vanguard group of mutual funds, wrote in his 1951 Princeton Bachelors degree thesis that the industry should form yet more closed end mutual funds like ARD to invest very small amounts of their total capital into venture capital.

Though Griswold (1943: 8) supported investing in ARD, he also proposed that the 1940 Securities Act be modified so that industrial corporations could invest in ARD believing that they would provide needed capabilities in evaluating new firms. When no changes were forthcoming, the promoters of ARD turned to the investing public. To ensure that investors were "patient", the founders specified that at least half of the initial capital had to come from trusts and other institutions. To allow registered investment companies to purchase ARD's common stock, ARD needed an exemption from the

\footnotetext{
${ }^{10}$ Ultimately, State Street would not invest in ARD.
} 
Investment Company Act of 1940. This was possible because Section 12(e) of the Investment Company Act of 1940 provided for exceptions for firms "engaged in the business of underwriting, furnishing capital to industry, financing promotional enterprises, and purchasing securities of issuers for which no ready market is in existence." As a listed investment company, ARD needed an exemption to allow it to own more than 3 percent of the stock of portfolio firms. ARD's ability to convince the Securities and Exchange Commission to grant these exemptions was probably due both to the social status of its backers as well as an agreement that $\$ 1.5$ million would come from institutional investors (ARD 1946a: 4-5).

ARD's goal was to raise $\$ 5$ million (or a net of $\$ 4,883,000$ ), though the minimum capital to begin operations was set at $\$ 3$ million provided that $\$ 1.5$ million was committed by institutional investors. By February 10, 1947, ARD had raised \$3,581,750 (ARD 1947:3). The institutional investors included investment trusts, life insurance firms, and university endowments (See Table 1). The roster of institutional investors indicates the prestige of the sponsors and the seriousness with which the New England establishment viewed the ARD experiment, and the willingness of institutions to commit a very small portion of their total assets to venture investing. Individuals contributed 46 percent of the total capital raised. To limit stockholding to investors that could afford long-term, high-risk investments, individuals were required to invest a minimum of $\$ 5,000$.

ARD utilized the prestige of its board of directors and stockholders to gain legitimacy and attract other investors. In its First Annual Report ARD (1946: 3) said:

"The Company is proud of its list of stockholders and sincerely hopes that they will continue to take an active interest in affairs. It desires a partnership with them that will be closer than that implied by the usual legal definition. The Company hopes that the stockholders will be interested, not only in the stock of the Company and its affairs of the past, but in the Company itself and its future. It has much to gain from their active interest."

ARD also hoped that its stockholders, both institutional and individual, would be a source of potential deal referrals.

ARD was established to validate the belief that a private organization could succeed financially by funding fledgling firms. However, venture capital was expected to do much more. It was supposed to 
commercialize technology, contribute to the economic recovery of New England, inspire the establishment and diffusion of a new organizational form, and be profitable. The following sections examine ARD's success in fulfilling these goals.

\section{ARD's Investments and Goals}

After raising capital and establishing its operations, the first order of business is to attract and review business plans. ARD received significant press and as Table 2 shows business plans quickly arrived. ARD was very selective from its inception and in any given year it never funded more than 4 percent of the total business plans received, percentages that differ little from current firms (Bygrave and Timmons, 1992). With no prior experience, ARD invested in a variety of fields. During its first five years, 66 percent of its investments were in chemicals and industrial equipment, but thereafter, investments in both sectors diminished. Gradually ARD developed an affinity for technology-based firms in electronics, data processing, scientific instruments and industrial equipment (see Table 2). From this we infer that ARD learned which fields were best suited for venture investing, and discovered that the information technology and electronics fields were best suited for venture capital investing. The industrial equipment investments appear to be associated with ARD's need to generate income from its portfolio firms to pay current expenses and to pay dividends to its investors.

The source of deals evolved over time. ${ }^{11}$ During the first five years, the percentage of internally sourced projects, i.e., from its own investment officers or its portfolio firms, was approximately 40 percent, and then decreased to approximately 20 percent. MIT- and Harvard-sourced deals declined from over 10 percent in the first five years to zero during the period from 1966-73. ${ }^{12}$ Investment banks and brokerages provided between 25 and 50 percent of the deals during the entire period. Then, as now, very few investments originated from unsolicited sources (Fried and Hisrich, 1994). Surprisingly, few deals

\footnotetext{
${ }^{11}$ Identifying the source of the deals was difficult, and during some five-year periods we were unable to identify the source of as many as 50 percent of the deals.

${ }_{12}$ Interestingly, MIT changed its policy of support for ARD after 1953 when MIT requested that its name be expunged from any ARD reports or any other ARD publications (Ford 1953).
} 
appear to have come through referrals from other venture capital firms. This suggests that the current norm of referrals and co-investing may not yet have become standard practice. ${ }^{13}$ Unfortunately, there is no complete recording of ARD's co-investors.

This section examines ARD's efforts to achieve the four goals set out for it by its founders. For a new organization, translating goals into viable business strategies and practices is often a trial-and-error process that advances through learning-by-doing. With the data available, we are able to define a set of organizational investment characteristics: the extent of R\&D intensiveness, stage of investment, location of the purposed investment, and choice of financing instrument. These are among the most important for the practice of venture capitalism. We examine changes in these investment characteristics by dividing ARD's investment career into two periods: the first (1946-1960) and the second (1961-1973). We choose this division because by 1960, a new environment for VC emerged as new competitors entered the industry (a discussion of the new competitors is contained below). ${ }^{14}$ Therefore, our statistical measurements can capture some of the broad changes in ARD financing practices over time. Though we cannot measure all of the variables that might have impacted changes, there is qualitative evidence to assist us.

Supporting Early-Stage Firms

ARD was founded on the premise of the need for a new financial institution to fund early stage start-ups, and yet only a relatively small number of early-stage investments were made in the first half of ARD's existence. To examine whether there were changes in investment stage, the variable INVESTED

\footnotetext{
${ }^{13}$ There was co-investment, however. For example, in 1948, ARD co-invested with Laurance Rockefeller in Island Packers, Inc., which was a tuna-fishing venture in the South Seas (ARD 1950). In 1950, ARD joined Laurance Rockefeller in purchasing Airborne Instruments Laboratory (Wall Street Journal 1950: 7).

${ }^{14}$ Until 1957 there were only three other significant organized venture capital operations, the Rockefeller Brothers, J. H. Whitney, and Payson \& Trask; all of which like ARD had begun operations in the immediate postwar period. In the late 1950s, the environment changed dramatically. In 1957 Draper Gaither and Anderson was established in the Bay Area; in 1959 the first federally-subsidized SBICs were formed and began investing in 1960, and in 1960 Davis and Rock was formed.
} 
EARLY was created. ${ }^{15}$ A $t$-test hypothesizing equal frequency in the first half of ARD's existence and second half of ARD's existence (see Table 3) easily rejects the null hypothesis. In the later time period, 57 percent of ARD's investments were in early stage investment, while in the earlier period only 21 percent were early stage investments. Because separating ARD's investments into the first and second half time periods is somewhat arbitrary, we also examined the differences by five-year intervals and found a similar pattern.

One possible explanation for the differences between the two periods was that, as the business press observed, venture capital was a social experiment and might be abandoned if the initial efforts failed. For example, Barron's (1949) reported: “Designed to meet that need [of growth capital for small businesses], venture capital companies today number fewer than ten, and their total resources probably do not exceed $\$ 25$ million by very much. If they prove to be successful, their example may attract important investors in large numbers to the field of venture capital." In Fortune (1952), this was stated more bluntly: "ARD realized that if it failed, or did only passably, the [venture capital] experiment might not be repeated." This mentality in the earlier time period likely encouraged ARD to fund existing firms that had lower risk and which could provide quick returns in the form of dividends, interest, or management fees. Liles (1977: 46) points out that the desire for management fees posed problems with other venture investors that did not charge fees. A second (though not mutually exclusive) explanation for the empirical pattern is that learning how to manage early stage investments may have created the institutional knowledge that facilitated the subsequent increase in ARD's early-stage investments. This possible explanation suggests that a broad range of experience derived from learning-by-doing on the part of an investment team is necessary to engage in early-stage venture capital investing. A third possibility is that

\footnotetext{
${ }^{15}$ The variable INVESTED EARLY is based on a memorandum by General Doriot in which he classified ARD's investments by the stage for all investments made between the years 1946-65 (Doriot 1966). Unfortunately, Doriot did not document his classification criteria. To classify the development stage of ARD investments made from 1966-73, we relied on interviews with former ARD investment officers James Morgan, Daniel Holland, and Charles Coulter. While utilizing different sources has obvious comparability limitations, there is no single source for comprehensive ARD development stage information for the entire period. When the interview data was not unanimous, we used a "majority rules" criterion for coding post-1966 observations. This occurred in approximately 25 percent of the cases.
} 
the "low hanging fruit" of investment opportunity may have been exhausted by the second period with increased competition for funding promising deals.

\section{Commercializing New Technologies}

A second ARD goal was to convert technological advances into commercialized products. To assess temporal changes in ARD funding to R\&D-based firms, we gathered business description information from ARD annual reports to create the variable, R\&D INTENSIVE, which includes all firms engaged in earth sciences, chemicals, industrial \& scientific equipment, electronics, or data processing/storage. During certain time periods, ARD invested in outlier industries such as food products (1946-50), ${ }^{16}$ professional services (1951-55 and 1961-65), and education and media (1966-71).

According to this measure, ARD invested in a high percentage of $\mathrm{R} \& \mathrm{D}$ oriented projects across its life 73 percent of its total investments were in a high-tech sector. A $t$-test of differences in means by time period suggests that ARD was more likely to invest in more $R \& D$-intensive projects in the first half of its life. In a 1961 speech to Chicago Security Analysts, Doriot recognized this change in investments and publicly stated that while technology-based ventures had been responsible for the lion's share of ARD's profits, the share of ARD's investments in R\&D-based firms was decreasing. The shift from R\&Dintensive projects is echoed in ARD's Annual Reports. For example, Doriot wrote in the 1955 Annual Report that its industrial sector interests included: applied physics, electronics, nucleonics, chemistry, thermo mechanics, instrumentation, and specialized equipment.

One possible explanation for the reduced level of investment in R\&D-intensive firms may have been the reduced demand for technology IPOs as a result of downturns in the business cycle. However, because recessionary periods were more likely in the first half of the sample period, this explanation does

\footnotetext{
${ }^{16}$ These investments were likely motivated by the new food preservation technologies developed during World War Two and the enormous success J. H. Whitney had in funding the firm commercializing Minute Maid frozen concentrated orange juice.
} 
not seem likely. And, in fact, the late 1960s were a period of frenzied investment in R\&D-intensive firms due to the stock market boom of the 1960s.

There are three factors that could have contributed to the observed outcome. First, Doriot may have been aiming to diversify ARD's portfolio of investments during the 1960s as DEC, due to its incredible increase in valuation from 1963 onwards, began to overwhelm the entire portfolio. Second, ARD's organizational form may have made it increasingly ineffective at securing high-technology deals. It is possible that ARD's investment professionals no longer were searching as aggressively for hightechnology opportunities. In an internal 1964 memo, Doriot complained that ARD officers were not exploring creative new ideas for investments, but were instead relying on "old knowledge" associated with a bygone era. In an internal 1965 memo, Doriot went further expressing the view that because ARD officers did not feel a "heavy responsibility" for the inflow of high quality projects, ARD was losing competitive ground. As we will discuss later, the inability to compensate ARD professionals may have contributed to their increasing inability to discover technology-based deals. This suggests that ARD may not have wanted to reduce its share of R\&D-based projects; rather the firm's reduced competitiveness may have contributed to the observed outcome.

However, the most likely explanation for the decline in R\&D-based investments was the heightened competition for deals in the venture capital marketplace after 1960. Competition came from both a federal initiative in 1958 to fund new ventures, small business investment corporations (SBICs), and from an alternate private form of organizing $\mathrm{VC}$, the limited partnership. These sources of competition are discussed below.

\section{Support for the New England Economy}

The importance of ARD to the New England economy is difficult to gauge. However, it is possible to calculate how many of its investments were in New England and to trace the careers of the investment professionals that left ARD. Also, ARD's investment in Digital Equipment Corporation ignited the Route 128 minicomputer boom that resulted in the formation of the world's largest cluster of 
minicomputer firms (Romanelli 1989; Earls 2002). Further, the entrepreneurial activities of the minicomputer industry alumni echoed down the decades, as they became important entrepreneurs and key executives in the workstation and computer networking industries.

In Figure 1 the percentage of ARD investments in Massachusetts, non-Massachusetts New England, the Midwest, the West, and "other" locations over time is plotted. To examine whether the geographic location of ARD's portfolio companies shifted over time, we created an indicator variable for MASSACHUSETTS LOCATED. This measure draws upon research that suggests VCs have strong tendencies to invest locally (Florida and Kenney 1988; Lerner 1995; Sorenson and Stuart 2001). T-tests of time period differences indicate that ARD was more likely to invest in Massachusetts-located firms in the first half of its operating career. If we include all of New England in its investment purview, then only in the 1951-55 period were less than 50 percent of its investments outside the region (Figure 1).

ARD made substantial investments in the Boston area. Further, as we discuss in more detail below, a number of professional VCs resigned from ARD to establish other venture capital firms in the Boston area, and they too invested locally. Overall, Boston's rise to a prime location for high-technology startups was a broader-based phenomenon than can be accounted for by ARD's investments (see, for example, The New Englander 1959). In summation, it is undoubtedly true that ARD and its investments had a significant demonstration effect and encouraged entrepreneurs and entrepreneurship in New England.

\section{Diffusion and Profitability}

ARD's backers understood from the beginning that the diffusion of venture capital as a financing institution was predicated upon profitability. Investors would not support venture capital without the prospect of an attractive return. According to Liles (1977: 83), ARD's annualized return excluding DEC from 1946 to 1971 was 7.4 percent per annum, "significantly below the compound return of 12.8 percent for the Dow Jones Industrial Averages (DJIA) for the same period." However, with DEC included, the rate of return was 14.7 percent compounded (Figure 2 shows the overwhelming impact that DEC had on 
ARD's net asset value). The success of ARD's DEC investment, which grew from a $\$ 70,000$ investment in 1957 to a gain of $\$ 355$ million in 1971 (when the remaining DEC stock was distributed), was an enormous spur for venture capital (Liles 1977: 83).

The ARD remit was seen as greater than simply being successful economically or supporting economic growth in New England. In an effort to broaden its effect, advisory boards were established in Philadelphia and Providence, Rhode Island. In 1962, ARD participated in the creation of affiliated venture capital firms in Canada and Europe. Then, in 1972 an affiliate was launched in Australia. Though profit was important, ARD also had the mission of spreading the concept of venture capital as a practice. ARD's First Annual Report for 1946 (ARD 1946: 12) stated “a financially successful operation will encourage the formation of similar and possibly related organizations in other parts of the country, [and] will enable this Corporation to increase its investments in individual enterprises and stimulate increased expenditures for research and development." Reflecting back, General Doriot (1967: 2719) said that at its inception, Senator Flanders stated, "American Research [sic] should not be looked upon as just one more company it should be looked upon as a movement. People ask me how we can do the work we do with the small staff I have and my answer is that my staff is the United States of America."

An unintentional method by which ARD helped diffuse venture capital was through the resignation of its investment officers. Though we will discuss the reasons for the resignations later, these investment officers were experienced and left to form their own firms. The first resignation came in 1951 when Joseph Powell, the first professional hired by General Doriot, resigned to accept a position as Vice President and Director at the Harris Intertype Corporation in Cleveland where he received an attractive package of stock options and other benefits (Powell 1987; Liles 1977). In 1960, Powell returned to venture investing when a Boston group formed the public SBIC, Boston Capital Corporation, and hired him as its first president. In 1965 William Elfers and James Morgan left to form what would become one of the premier venture capital firms, Greylock. In 1970, Henry Hoagland left to establish Fidelity Ventures, and then in 1971, William Congleton and John Shane formed Palmer Partners - all three of 
these were limited partnerships. These became core firms in the Boston venture capital community and continued to practice the Doriot-style of venture investing.

An important avenue for the diffusion of the concept of venture capital and the ARD way of investing was Doriot's class at Harvard Business School entitled "Manufacturing." In this class, Doriot expounded on how venture capitalism should be practiced, inspiring a number of students to try venture capital investing (Doriot 1993). Among those so inspired were Arthur Rock (class of 1951) and Thomas Davis (founder of the Mayfield Fund), who met Doriot through his brother, who had taken Doriot's class. Davis explicitly credited Doriot's influence as one reason he entered venture investing (Davis 1986).

Profitability would be crucial to the diffusion of the model so we developed some crude measures of performance. The measure of performance is a dummy variable, GAIN, which takes the value of one if ARD's liquidation of the portfolio firm's securities resulted in a gain, net of the costs of acquiring the securities. ${ }^{17}$ While Figure 3 plots GAIN and the number of IPOs over five year time intervals, a $t$-test of the mean GAIN in the earlier and later half of the sample indicates that GAINs were more prevalent in the earlier period - this includes the investment in DEC.

Statistical examination of the performance of ARD's portfolio firms (using the GAIN measure) shows that R\&D INTENSIVE is positively correlated with GAIN in the bivariate case (see the first column in Table 4). This result resonates with the observation by Merrill Griswold in a 1952 article in

\section{Fortune that:}

"Some of our friends began to say, 'Oh, Lord, not another longhair project. Why doesn't A.R.\&D. back something commercial and make some money?' We learned our lesson. Now we realize that our best things are longhair. If they click we're not trying to do something that everyone else can do."

The second column of Table 4 tests time period effects by examining five-year increments in ARD financing history. Because the excluded time period is 1966-73, the results suggest that relative to the

\footnotetext{
${ }^{17}$ GAIN and IPO, a variable indicating whether a portfolio firm went public, are pair-wise correlated at the 5 percent level. As well, a univariate test of means of the rate of IPO between the first and second halves of ARD existence finds a significantly higher rate in the first half, a result in accord with that for GAIN. The GAIN measure was used because only eight ARD-backed firms were taken public and acquisition exits were a prominent and often profitable outcome.
} 
final time period, investments between 1951-65 were more likely to result in a gain. The third column reveals that the R\&D INTENSIVE coefficient is positive and is strengthened by inclusion of proxies for time-period effects. Finally, model (4-4) suggests that adding measures of development stage (INVESTED EARLY) and location (MASSACHUSETTS LOCATED) does not alter the R\&D INTENSIVE result. In this last regression equation, MASSACHUSETTS LOCATED is also positively correlated with GAIN, as are the time dummies for the 1951-60 period.

The location result is consistent with at least two interpretations: (1) ARD was better able to monitor and/or assist local investments, and (2) Massachusetts firms were of "higher quality" before and/or after the ARD investments. Unfortunately, we do not have data to further address these possible interpretations. Furthermore, reverse-causality, i.e. the possibility that R\&D intensity of investments shifted as a result of gains (or lack thereof), cannot be ruled out. Nevertheless, the estimated economic effects from (4-4) are large, with discrete changes of R\&D INTENSIVE and MASSACHUSETTS LOCATED from zero to one associated with 21 percent and 18 percent increases, respectively, in the probability of a GAIN at the mean of the other independent variables. Given the strong MIT representation on ARD's board and the initial goal, it is unsurprising that several of ARD's initial investments were MIT-affiliated. ${ }^{18}$ For example, one of ARD's earliest (and very profitable) investments was in High Voltage Engineering Corporation, a firm started by two MIT professors, and brought to ARD's attention by MIT President, Karl Compton. After licensing the underlying patents from the Research Corporation ${ }^{19}$, High Voltage started commercializing a 1 million volt Van de Graaf particle accelerator - the first of its kind.

The influence of ARD on the diffusion of venture capital as a practice and an institution in many ways cannot be separated from the persona of General Doriot and the inspiration he provided to many fledgling venture capitalists. Attributing the current venture capital industry to ARD is an exaggeration,

\footnotetext{
${ }^{18}$ Karl Compton, the President of MIT, Edwin Gilliland, an MIT Professor of Chemical Engineering, and Jerome Hunsaker, head of the MIT departments of Mechanical and Aeronautical Engineering, were on ARD's board of advisors. Horace Ford, the MIT Treasurer, was on the ARD board of directors.

${ }^{19}$ see Mowery and Sampat [2001] for a history and analysis of the Research Corporation.
} 
but ARD alumni were central to the growth of the Boston area venture capital community. Moreover, $\mathrm{ARD}$, as an independent private firm, provided an example and inspiration to the next generation of venture capitalists entering the industry in the early 1960 s.

\section{A Problematic Organizational Form}

The passage of federal legislation in 1958 authorized the creation of small business investment corporations (SBICs), which aimed to provide funding to small firms. The initiative resulted in the creation of several hundred SBICs in less than four years. Many of these were formed expressly to invest in VC situations (others were content to provide loans to existing businesses). The SBIC program offered a significant subsidy to its licensees. To receive an SBIC license an applicant organization had to have at least $\$ 150,000$ in paid-in capital for which it could receive the maximum 200 percent leverage in the form of a combination of 15-year loans and 20-year subordinated debentures that carried a favorable 5 percent interest rate. For investments greater than $\$ 150,000$, the leverage decreased on a sliding scale. This feature was significant, because it favored the formation of small SBICs. The most important other benefits were tax incentives permitting profits from investing in an SBIC to be taxed at the capital gains rate of 25 percent rather than the much higher ordinary income tax rates that for the wealthiest persons were as high as 90 percent. All losses could be taken as ordinary losses. The SBICs could disburse their investments as either loans or a loan with debentures convertible to common stock. In 1963 this was modified to allow investment in any type of financial instrument issued by a small firm.

SBIC legislation also provided for SBICs that raised capital by issuing stock on the public market to raise investment capital. These firms would be direct competitors to ARD. Compensation and other rules that applied to ARD as a closed-end fund did not handicap these SBICs, however. Finally, banks were permitted to form SBICs using up to 5 percent of their paid-in capital, allowing them to circumvent the exclusion from owning industrial corporations. In effect, the federal government was unleashing a torrent of new competition for the provision of venture capital. SBICs of all three sorts were formed throughout the nation. In New England, all of the major banks, especially the Bank of Boston, 
established SBICs, and began investing locally. Most important for ARD were the public stock SBICs that quickly became direct competitors.

Though ARD did not take a public position on the SBIC legislation, many in Boston supported the program. Not everyone in the existing venture capital community favored the SBIC program, because they believed that it would crowd out their investments. For example, Robert Stillman (1999) of Payson and Trask recalls the mood in his firm to the news that the Federal government had created the SBIC program,

"The reaction of those of us who were in the business to the idea of an SBIC program was that it was absolutely just not needed at all... We were all sitting there with uninvested capital and were struggling to fund the deals... We felt that all the new money would just crap it up for everybody."

This was not the only sentiment, however. Peter Crisp (1999), then a young associate at the Rockefeller Brothers, remembers a more benign view saying that the Rockefeller operation even discussed whether they should take advantage of the SBIC program.

The bull stock market from 1959 through the beginning of 1962 was receptive to both the SBICs raising public capital and initial public stock offerings of high-technology electronics firms. One of the earliest SBICs, Electronics Capital Corporation (ECC), received its license in June 1959, and then raised $\$ 18,000,000$ in a public stock offering, so it was immediately larger than ARD in paid-in capital. ECC's success in selling its own stock prompted other SBIC offerings. ECC's real significance was its first investment, a $\$ 1$ million loan partially convertible to a 33 percent equity stake in Potter Instruments, a manufacturer of data processing equipment. Only eight months later Potter Instruments went public and the investment had a market value of \$11 million (Kelley 1966; Nason 1963). This success legitimated the SBIC as a business proposition, and encouraged the establishment of more public SBICs. During the bull market of the period, the stocks of the new SBICs rapidly increased in value. In July 1960, The New York Times described the situation aptly: "Wall Street, seldom swift to bestow its affections, has found a new darling - the small business investment company" (Kraus 1960: 1). Attracted by the vision of easy capital gains, in the early 1960s, there was a wave of new entrants into venture capital. By 1962, Culver 
(1973), a SBA administrator, estimated that the public had invested $\$ 400$ million in nearly 50 publicly owned SBICs.

For ARD, the SBICs would prove to be competitors as Doriot mentioned in a memo (Doriot 1970). In fact, Joseph Powell, Doriot's first assistant, who had left to join an operating company was lured back to Boston to form Boston Capital Corporation (an SBIC), and thereby entered into direct competition with ARD. However, by the mid 1960s there had been a powerful market correction, and many SBICs had become embroiled in financial mismanagement and corruption.

Even as the SBIC program got underway, another organizational form that would be far more powerful was being adapted for VC investing, namely the venture capital limited partnership (VCLP). The limited partnership organizational form was adapted from the oil wildcatting business and had a number of beneficial features. First, all profits could be directly passed on to investors without being taxed. This was more desirable than the corporate form. Second, the general partners not only received a management fee that covered their salaries and expenses, but they also received a share of the capital gains. This allowed them to profit significantly from the successes of their investments. Third, taking the management fee from the investment principal eliminated any pressure for investment or dividend income to pay for the ongoing operations of the venture capitalists. Fourth, the limited partners were sophisticated institutional investors that were interested in the long-term returns and thus did not provide pressure for dividends or interest payments. Fifth, the limited partners had little ability to affect the policies of the general partners. In fact, they were mandated to stay entirely out of the management process thus freeing the general partners from interference. Sixth, each partnership had a limited life usually 10 years after which time it was liquidated. Seventh, the funds were invested only once, and all returns were immediately distributed to the investors - and so VCLP was self-liquidating. If the limited partnership was successful it would simply raise the next partnership. For the portfolio firm, there would be no obligation to pay interest or dividends.

In 1959 the first limited partnership, Draper, Gaither \& Anderson, (DGA) was organized in Palo Alto by three influential individuals and received its capital from four wealthy families. DGA was 
liquidated in 1967 and no follow-on fund was raised (Lucas 1999). However, in 1961 another fund, Davis \& Rock (D\&R), was formed by Arthur Rock and Thomas Davis attracting money from various successful San Francisco Bay Area entrepreneurs. D\&R was enormously successful and when it was liquidated in 1970 , had disbursed $\$ 100$ million in return for the initial $\$ 3$ million investment. As compensation, the general partners Davis and Rock received 20 percent of the capital gains (Davis 1986). In 1965, William Elfers, formerly of ARD, left and formed the first Boston area VCLP, Greylock. By the late 1960s, other VCLPs were being formed especially in Silicon Valley, but also in other regions including Boston. Perhaps the turning point was in 1969 when Edward Heizer raised \$81 million from institutional investors proving that they would commit money to the VCLP format (Heizer Corporation 1974).

By the mid 1960s, the SBIC and VCLP were becoming established organizational forms, and they began competing with ARD for deals. Moreover, both organizational forms were interested in hightechnology deals, exactly the area in which ARD had found its best deals. The ARD organizational form was handicapped in that it could not draw upon government subsidies provided to the SBICs, and did not have the flexibility or ability to compensate its professionals in a manner competitive with the limited partnerships.

ARD's organizational structure exacerbated the effects of an increasingly competitive environment to fund the most promising ventures. Pioneering organizations frequently are ill adapted for the functions they are meant to discharge (Stinchcombe 1965). The fact that ARD was a closed-end investment fund proved to be problematic in three important ways: First, the investment fund structure pressured ARD's management to generate a steady stream of cash. Second, it inhibited the provision of competitive compensation for ARD's investment professionals, thereby reducing their incentives and eventually leading them to resign. Third, closed-end investment funds often trade at a discount to their value in terms of cash and marketable securities thus making them targets for corporate raiders. According to Liles (1977: 79-80), during a large part of its existence ARD traded at a discount to the value of its assets. For example, at the end of 1968, ARD traded at a discount of 29.9 percent to its "cash, 
near-cash, and 97.6 percent of its portfolio" (Liles 1977: 80). These difficulties became problematic when alternative organizational forms were introduced - something that happened in the late 1950s, and became a serious competitive threat in the 1960 s with increasing competition with the new organizational forms.

\section{Investment Criteria and Practices}

ARD's purpose was to provide equity capital, and so in this section we examine ARD's financing methods. In a Fortune article (Bello 1952) reporting on ARD's financing practices, “As a rule, ARD likes to invest some of its money in the form of notes or debentures, and the rest in voting stock to acquire part ownership [of the firm], usually 20-35 percent...Management fees are now a frequent part of the ARD package." Several years later, ARD reported that it was tailoring its financing method to the particular situation, as stated in its 1961 annual report: "ARD has no specific formula for financing companies. Each investment opportunity is considered individually, and the form of the financing is dictated by the individual requirements of the situation." ARD's methods contrasted with some of the other early venture capital firms such as the Rockefeller Brothers whose financing method was described in this way, "Rockefeller Brothers invests only in established concerns with the nucleus of a sound management, and buys mostly common and convertible preferred stock (occasionally taking debentures)" (Fortune 1949).

The closed-end investment fund format affected the types of financing ARD provided and, as discussed earlier, influenced its choice of investments. Investor pressure to receive dividends meant that ARD had to extract cash flow from at least some of its investments. Requiring dividends or management fees from early-stage firms is perverse, because they are consuming capital to fund their growth. If the dividends or fees are collected immediately, the small firm's growth is slowed and the risk of failure is increased. If the fees are deferred and the firm fails, there are usually few assets to recoup the principal, much less accrued interest or fees. ARD had to deal with this difficulty by deciding what types of funding to use on a case-by-case basis. In contrast, the family funds and later the independent venture capital 
limited partnerships, almost solely used equity or equity-like financial instruments because they did not need an ongoing income stream.

To judge whether ARD's financing methods changed over time we developed a rudimentary quantitative classification scheme that provides some insight into whether ARD "learned" to tailor its financial instrument choice to investment situation over time. ${ }^{20}$ We coded the method used to finance each of the ARD portfolio companies into either DEBT-ONLY or EQUITY-ONLY (with the excluded category as using both debt and equity financing) from ARD's annual reports. ARD used DEBT-ONLY instruments (which excludes those financings with warrants for equity participation) in 15 percent of its deals over the 1946-73 time period, while using EQUITY-ONLY instruments in 34 percent of the deals in that period. $T$-tests of means for both of these variables do not reveal any statistical differences between the first and second halves of ARD's operational history. However, because the form of financing may itself depend on the portfolio firm's characteristics, most notably the amount of uncertainty, an analysis controlling for these factors can provide further insight. Table 4 presents the results of multinomial logit regressions modeling ARD's decision as a choice between DEBT-ONLY, EQUITY-ONLY, and a combination of the two as the excluded choice. (3-1) presents a regression for the sub-sample of ARD investments made between 1946-1960 with two measures correlated with potential agency problems: R\&D INTENSIVE and INVESTED EARLY. ${ }^{21}$ The use of EQUITY-ONLY is not correlated with these measures of agency, while R\&D INTENSIVE is negatively correlated with DEBT-ONLY financing. This suggests that ARD did attempt to match financing method to project type from the early years of its investment history. This R\&D INTENSIVE result is robust to the geographic proximity of the portfolio company to ARD, MASSACHUSETTS LOCATED, as well as to whether the project was ARD SOURCED. Moreover, the estimated R\&D INTENSIVE effect is large, with a discrete change in R\&D INTENSIVE to non-R\&D INTENSIVE investments associated with a 11 percent decrease in the likelihood of using a debt-only financing instrument relative to using a debt and equity financing option.

\footnotetext{
${ }^{20} \mathrm{We}$ were unable to establish which portfolio firms paid ARD a management fee. ${ }^{21} \mathrm{R} \& \mathrm{D}$ INTENSIVE is defined as before; INVESTED EARLY is a dummy $=1$ if ARD created or invested early in the portfolio company. These are used as measures of agency in the literature (see Gompers and Lerner, 1999).
} 
In Table 5, column (3-2) indicates that the same regression specification for the 1961-1973 sub-sample no longer shows a correlation between R\&D INTENSIVE and DEBT-ONLY. These analyses are consistent with the proposition that ARD's founders had the "right" idea of financial structuring from the start. However, their organizational form mandated consideration of how to ensure income to pay for ongoing operations.

\section{Retention of the Investment Professionals}

The choice of an organizational form can determine the compensation schemes adopted by an organization. As a closed-end investment company, ARD's operations were subject to SEC regulation under the Investment Company Act of 1940. To prevent conflicts of interest, the 1940 Act prohibited investment organization personnel from taking equity stakes or receiving options in either their investment company or in their portfolio companies. ${ }^{22}$ For this reason, compensation for ARD's professional staff was in wages and bonuses, and because venture capital investments mature slowly, there was constant pressure to control wages. The salaries for the ARD investment professionals were significantly below market rates.

These restrictions proved to be a severe constraint on ARD's competitiveness. An internal memo Doriot (1968) wrote lamented that that the "SEC never understood, and I believe made an effort to understand the problems of compensation of ARD personnel." He continued "it is difficult to convince top quality individuals, particularly younger ones, to work for ARD when it could not offer options. It was especially difficult to explain to ARD's investment officers why they should work so hard for an ARD portfolio company instead of a portfolio firm where they could receive options." Doriot felt that ARD had lost good projects due to weak financial incentives for his investment officers. Charles Waite (2000), a former ARD investment officer, recalled placing a considerable effort in the early 1960s into assisting an ARD portfolio company, Optical Scanning. After managing to both resurrect the venture and

\footnotetext{
${ }^{22}$ This differed markedly from the investment professionals in the limited funds where immediate profitability was not as important (Crisp 1999; Ackerman 1999).
} 
eventually take the stock public, the founder and president of the company was worth $\$ 10$ million, while Waite only received a $\$ 2,000$ bonus. Doriot blamed the lack of investment officer initiative on the lack of incentives and believed this contributed to the "aging process" at ARD.

These restrictions became a severe problem in the mid 1960s because both the limited partnership and the SBIC provided superior compensation possibilities for the $\mathrm{VC}$ professional. Investment successes made it clear that there were significant capital gains that could be created, but the professionals at ARD could not share in the rewards. It was the enormous success of DEC that made the ARD professionals question the fairness of ARD's compensation scheme. With DEC, the wealth generated and exceeded anything they could have imagined and made it plain to the investment officers that there were enormous opportunities outside ARD. ${ }^{23}$

\section{Managing the Portfolio Firm}

Already prior to World War Two, the founders of ARD understood that venture capitalists had to monitor and assist their portfolio firms. Doriot or other ARD officers typically joined the boards of directors of their portfolio companies in order to monitor and when necessary, actively participate in the managerial direction of the firm. ARD's post-investment practice, one of balance, became known as the "Doriot style" of active investment. ARD intended to actively participate in portfolio firms by providing advice and assistance without unduly infringing the entrepreneur's autonomy in decision-making.

However, at times more drastic measures were necessary, and, if ARD controlled the firm, Doriot was willing to remove the president. For example, in ARD's 1950 Annual Report, Doriot wrote, “[With reference to Circo Products], for the three year period since this investment was made, the company has operated at approximately a break even basis. Since no substantial progress has been made toward retiring the debt, AR\&D reached the conclusion that top management should be replaced. In January 1950,

\footnotetext{
${ }^{23}$ In institutional terms, the compensation and structure issues were critical. But, according to William Elfers (1995), the successes the investment officers experienced made them want to operate as the CEOs of their own venture capital organizations. This was not likely to occur at ARD, where Doriot was the personification of the firm. To this day, succession issues are a critical issue in venture capital partnerships.
} 
AR\&D acquired voting control through a recapitalization and installed a new operating head.” Despite this active stance, a 1967 Fortune article reported that certain critics faulted Doriot for not replacing top managers at some portfolio firms soon enough. Doriot is quoted in the article as indicating it was not ARD's ordinary policy to replace the head of a company it had backed, and that he found the task of replacing top managers quite unpleasant.

Active participation was not confined to the board of directors' meetings. Doriot kept logbooks on the portfolio companies, in one case even speculating on the effects of an entrepreneur's marital problems on his productivity. Doriot made a note to hire a maid for this entrepreneur so that more time could be spent on the work of the company rather than doing work around the house (Doriot 1949). In the case of DEC, Doriot reportedly insisted on meeting Ken Olsen's wife prior to investing in the firm (Rifkin and Harrar 1988:15). Also, in certain situations, ARD personnel were dispatched to assist in managing portfolio firms (Elfers 1995; Waite 2000).

Another practice ARD utilized was the staging of its investment rounds, which is now a common VC practice. In an undated internal ARD memorandum (Doriot, undated), Doriot commented on the importance of staged funding:

Any financing must be done or should be done in such a way as to make the next one less expensive to the company. In other words, there must have been an element of progress, of success, before the next financing is necessary...There are many reasons why it is advisable for the new company to have a limited amount of capital at its disposal at the very start. One of the main reasons is that in the hands of an inexperienced person commitments of all types are often made quite recklessly and capital has a way of disappearing at a remarkable high rate of speed. At that time, being limited as to expenditures is a good form of training.

ARD was effective in nurturing its entrepreneurs. Balancing the interests of entrepreneurs and ARD shareholders meant developing practices such as actively participating on the board of directors in its portfolio firms and staging investments, practices that came to define the practice of venture investing.

ARD was never able to overcome the limitations of the publicly-owned investment trust model.

Given the combined problems of increased competition to invest in the most promising ventures and ARD's inability to restructure itself to effectively compete with new entrants, General Doriot relented to 
investment bankers' suggestions to a sell-off, and in 1973 ARD was sold to Textron. Though ARD continued to operate as a subsidiary of Textron, it was no longer significant for the development of the venture capital industry.

\section{Conclusion}

Venture capital today is a taken-for-granted institution in the U.S. political economy and is recognized as a cornerstone of the U.S. national system of innovation. We have shown that its origins are in the New England civic and academic elites that believed that new firms commercializing technology developed in research laboratories would provide a solution to the economic decline of their region. They recognized that such small firms would require not only financial support, but also business assistance. To that end, ARD required a professional staff able to both evaluate business opportunities and provide fledgling firms with support and assistance.

Though venture capital would become a part of the U.S. economy, ARD suffered from organizational design flaws that ultimately proved fatal, primarily because it was incapable of providing sufficient reward to its investment professionals. When competitor organizations, the SBICs and VCLPs, entered the field, ARD's design flaws were exposed. Ultimately, due to the difficulty of reorganizing, Doriot distributed ARD's DEC stock and sold the firm to the conglomerate Textron. However, by this time venture capital had become a part of the economy and ARD simply slipped out of existence with its historical mission accomplished.

ARD's sponsors believed that the Great Depression-era stock market and banking reforms, combined with the tendency for the wealthy to invest their funds in trusts of various sorts including mutual funds, disrupted the flow of capital to new firms. They also felt that new firms would be vital to the creation of new industries and be an engine of economic growth by fostering innovation that could unleash gales of creative destruction. ARD's organization as a closed-end New York Stock Exchangelisted investment fund was tailored to attract a small portion of the mutual funds' capital. Though it was successful in attracting some capital, the mutual funds showed little further interest in investing in closed- 
end venture capital organizations. Though initially the VCLPs attracted capital from families and wealthy individuals, their real success and rise to dominance came when they began attracting institutional capital from endowments and pension funds. Here, the long-term strategies of the investors matched the capabilities of VCLPs. Mutual funds would never be an important source of venture capital. ARD's backers recognized the need for long-term capital (and did attract some monies from university endowments), but they sought funds from the wrong institutions.

Venture capital evolved from a local response to an economic crisis to a significant constituent of the U.S. national innovation system. A remarkable number of the institutional practices and goals pioneered by ARD's founders remain relevant today. The founders understood the importance of professional evaluation and after-investment support to portfolio firms. Remarkably early, they discovered that the greatest gains could be captured from high-technology start-up investments, even though they were handicapped by the need to generate income, which was difficult from start-ups. ARD's success with DEC demonstrated that the venture capital business could generate enormous capital gains, and also demonstrated that ARD's compensation system was inadequate. Professionals could capture more benefits in differing organizational forms.

Venture capital evolved into a market solution to the problem of how to fund innovations that fell outside existing corporate boundaries. As Griswold recognized, venture capital would be most successful where it was able to pioneer new economic spaces. With the growth of the venture capital industry and, particularly, after ARD's funding of DEC, existing computer firms would never again dominate the new niches that emerged. It is possible to argue that it was venture capital that provided the funds to establish a biotechnology industry that was distinct from the pharmaceutical industry (Kenney 1986). From a response to the difficulties faced by small firms and the ideological struggles about the role of science and technology in U.S. society, ARD was the linchpin in creating a new national innovation system that was not predicated upon the commercialization of research by large established corporations. 


\section{References}

American Research \& Development (1946a) Prospectus (Boston: American Research and Development) August 8.

American Research \& Development (1946b), First Annual Report, (Boston: American Research and Development).

American Research \& Development (1947), Second Annual Report, (Boston: American Research and Development).

American Research \& Development (various years), Annual Report to Shareholders, 1946-1971.

Barron's (1949), “New Kind of Company Finance Ventures,” February 21, 5-6.

Bello, Francis (1952). "The Prudent Boston Gamble," Fortune, November, pp. 124-125,208, 210, 213 216.

Bogle, John C. (1951). The Economic Role of the Investment Company A.B. Degree Thesis, Department of Economics and Social Institutions, Princeton University (April 10).

Bullock, Hugh (1959). The Story of Investment Companies (New York: Columbia University Press).

Bush, Vannevar (1945), Science: The Endless Frontier. U.S. Government Printing Office: Washington DC.

Business Week (1946a), “Dynasties Unify,” June 15, 21.

Business Week(1946b), “Investment Test,” August 10, 36.

Business Week (1946c), “Adventure Capital,” August 17, 62-63.

Bygrave, W.D. and J.A. Timmons (1992). Venture Capital at the Crossroads. Harvard Business School Press: Boston.

Chandler, A. (1977). The Visible Hand. Belknap Press of Harvard University: Cambridge, MA.

Compton, Karl T. (1939). "Science Makes Jobs." Speech to the American Institute of Physics and the New York Electrical Society (February 22).

Compton, Karl T. (1939). "New Ideas and Capital for Industrial Progress." New England News Letter (April): 2.

Compton, Karl T. (1940). "Science, the Soul of Prosperity." Vital Speeches of the Day (March 15) 6, 11: 322-324.

Doriot, General Georges (1993). Georges F. Doriot Manufacturing Class Notes Harvard Business School 1927-1966 (Boston: French Library). 
Doriot, General Georges (1967). Statement of Gen. Georges F. Doriot, President, American Research and Development Corporation, Boston, MA. Hearings before the Subcommittee on Antitrust and Monopoly of the Committee on the Judiciary of the U.S. Senate, $90^{\text {th }}$ Congress, First Session, Part 6 (September 1927, October 2-6).

Earls, Alan R. (2002). Route $128 \&$ the Birth of the Age of High Tech (Charleston, South Carolina: Arcadia Publishing Company).

Elfers, William (1995). Greylock: An Adventure Capital Story (Boston: Greylock Management Corporation).

Etzkowitz, Henry (2002). MIT and the Rise of Entrepreneurial Science (London: Routledge). Florida, Richard and Martin Kenney (1988). "Venture Capital, High Technology and Regional Development." RlegidnaRStardeN128(in)bes-(418.94), "Capital and Creative Destruction: Venture Capital, Technological Change, and Economic Development," working paper, Heinz School of Public Policy and Management, Carnegie Mellon University, May.

Fortune (1945). "Flanders of New England.” August, 135-136, 264-272.

Fortune (1949). "Venture Capital," February, 84.

Fortune (1952). "The Prudent Boston Gamble,” November, 124.

Fortune (1967). “General Doriot's Dream Factory,” August, 103.

Fried, V.H. and R.D. Hisrich (1994). "Toward a Model of Venture Capital Investment Decision Making," Financial Management, 23, 28-37.

Gerschenkron, A. (1966). Economic Backwardness in Historical Perspective. Harvard University Press: Cambridge, MA.

Gompers, P. (1994). “The Rise of Venture Capital,” Business and Economic History, 23, 1-24.

Gompers, P. and J. Lerner (1999). The Venture Capital Cycle. MIT Press: Cambridge, MA.

Griswold, Merrill (1943). “Comment upon 'The Average Investor as Future Risk-Taker.” New England War Bulletin Supplement (October): 8.

Heizer Corporation (Circa 1974). "Heizer Corporation Description.” Mimeo.

Kaplan, A.D.H. (1948). Small Business: Its Place and Problems, New York: McGraw Hill, Committee for Economic Development Research Study, pp. 156-80.

Lazonick, William (1991). Business Organization and the Myth of the Market Economy Cambridge, U.K.: Cambridge University Press.

Lerner, J. (1995), "Venture Capital and the Oversight of Privately-held Firms," Journal of Finance, 50, 301-318.

Lewis, Jonathan E. (2002). Spy Capitalism: Itek and the CIA (New Haven: Yale University Press). 
Liles, P. (1977), Sustaining the Venture Capital Firm. Management Analysis Center: Cambridge, MA.

Morton, William F. (1943). "Investment Funds for the N.E. Promotion Capital." New England War Bulletin Supplement (October): 6.

Mowery, D.C. and B. Sampat (2001). "Patenting and Licensing University Inventions: Lessons from the History of the Research Corporation," Industrial and Corporate Change, 10, 317-355.

New England Council (1929). A United New England: Four Years of Progress (Boston: New England Council).

New England Council (1943). "The Sources of Venture Capital for New England Business." New England War Bulletin (October): 1-9The New Englander (1959). "The Giant in Our Midst." (October): $15,35,36$.

New England News Letter (1949). "N.E. Money Backs New Firms.” New England News Letter (May): 45 .

New York Times (1946a). "Research Venture Gets SEC Blessing.” New York Times (August 9): 24.

New York Times (1946b). "Six Rockefellers to Invest Jointly.” New York Times (April 23): 24.

Noone, C. and S. Rubel (1970). SBICs: Pioneers in Organized Venture Capital. Capital Publishing Company: Chicago.

Olsen, K. (1983). Digital Equipment Corporation: the First Twenty-five Years. Newcomen Society in North America, New York.

Reiner, Martha Louise (1989). "The Transformation of Venture Capital: A History of the Venture Capital Organizations in the United States," Ph.D. dissertation in Business Administration, University of California, Berkeley.

Rifkin, Glenn and George Harrar (1988). The Ultimate Entrepreneur: The Story of Ken Olsen and the Digital Equipment Corporation (Chicago: Contemporary Books).

Roberts, E. (1991). Entrepreneurs in High Technology: Lessons from MIT and Beyond. Oxford University Press: Oxford, UK.

Romanelli, E. (1989). "Environments and Strategies of Organization Startups: Effects on Early Survival." Administrative Science Quarterly 34: 369-387.

Rubenstein, James M. (1992). The Changing U.S. Auto Industry: A Geographic Analysis (London: Routledge).

Scott, Otto J. (1974). The Creative Ordeal: The Story of Raytheon (New York: Athaneum).

Sorenson, O. and T.E. Stuart (2001), "Syndication Networks and the Spatial Distribution of Venture Capital Investments," American Journal of Sociology, 106: 1546-1586.

Stinchcombe, Arthur L. (1965). "Social structure and organizations." In J. G. March (ed.), Handbook of Organizations Chicago: Rand-McNally pp. 142-193 
U.S. Bureau of the Census. 1905, 1920, 1930, 1940. Census of Manufactures (Washington, DC: US GPO).

Waite, C. (2000). "Greylock Management," in U. Gupta, editor, Done Deals: Venture Capitalists Tell Their Stories. Harvard Business School Press: Boston.

Weber, Max. 1968. Economy and Society: An Outline of Interpretive Sociology New York: Bedminster Press.

Wall Street Journal. 1950. “Airborne Instruments Laboratory Changes Hands.” Wall Street Journal (December 15): 7. 


\section{PERSONAL INTERVIEWS}

Ackerman, Dan (Investment officer in J.H. Whitney). 1999. Telephone Interview by Martin Kenney (September 20).

Crisp, Peter (Investment officer in Rockefeller Brothers, Inc. and then Venrock). 1999. Telephone Interview by Martin Kenney (September 20).

Davis, Thomas (founder of Davis and Rock and founder of the Mayfield Fund). 1986. Interview by Martin Kenney and Richard Florida (December 16).

Lucas, Donald L. (partner in Draper, Gaither and Anderson). 1999. Telephone Interview by Martin Kenney (October 13).

Powell, Joseph (first employee hired by General Doriot at ARD and founder of Boston Capital Corporation) 1987. Personal Interview by Martin Kenney and Richard Florida (June 24).

Stern, Julian N. (former chairman of Heller Erlich and lawyer that organized the Davis \& Rock partnership) 2002. Telephone Interview by Martin Kenney (March 20).

Stillman, Robert (former investment officer at Payson and Trask). 1999. Telephone Interview by Martin Kenney (July 13).

\section{ARCHIVAL MATERIALS CITED}

Compton, Karl T. 1946. Memorandum to File, New Enterprises, Inc. (March 14) AC4, Box 159, Folder 1.

Compton, Karl T. 1941. Industrial Development in New England." Speech delivered the joint meeting of the New England Council and American Association for the Advancement of Sciences (June 24) AC4, Box 158, Folder 8.

Compton, Karl T. 1940. Letter from Karl T. Compton to R. B. Cross" (October 14) AC4, Box 158, Folder 7.

Cross, Richard B. 1939. Memorandum from Richard B. Cross to Karl T. Compton" (October 24) AC4, Box 158, Folder 3.

Cross, Richard B. 1940a. Letter from Richard B. Cross to Howard A. Poillon" (December 19) AC4, Box 158 , Folder 7.

Cross, Richard B. 1940b. Letter from Richard B. Cross to Howard H. Brown" (August 30) AC4, Box 158 , Folder 6.

Doriot, Georges. Undated. "Internal Memorandum on Follow-on Funding."

Doriot, Georges. 1949. "Confidential Internal Memorandum from Tracerlab, Inc. Log Book.”

Doriot, Georges. 1964. "Internal Memorandum on ARD Investment Professionals."

Doriot, Georges. 1965. "Internal Memorandum on ARD Officers." 
Doriot, Georges. 1968. "Confidential Memorandum entitled Notes on ARD’s Position.” (November 9).

Doriot, Georges. 1970. “ARD Notes - Projects.” (May).

Ford, Horace. 1953. Memo from Horace S. Ford to J. R. Killian.” (May 18) AC4, Box 42, Folder 13.

New England Industrial Research Foundation, Inc. 1941. "Charter” (August 19) AC4, Box 158, Folder 8. 
Figure 1: Geographic Location of ARD Investments, 1946-73

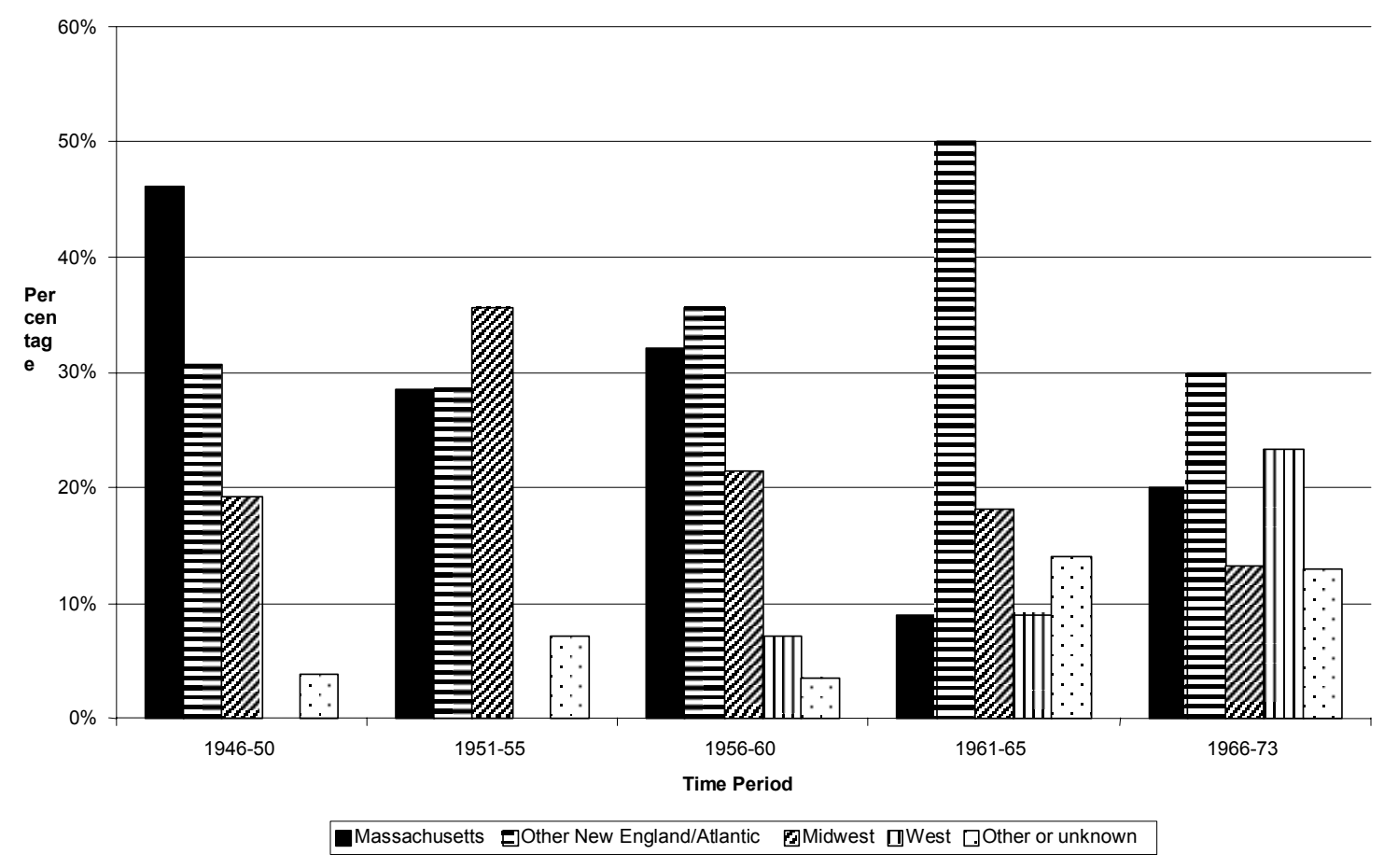


Figure 2. American Research and Development Net Asset Value, 1946-1971

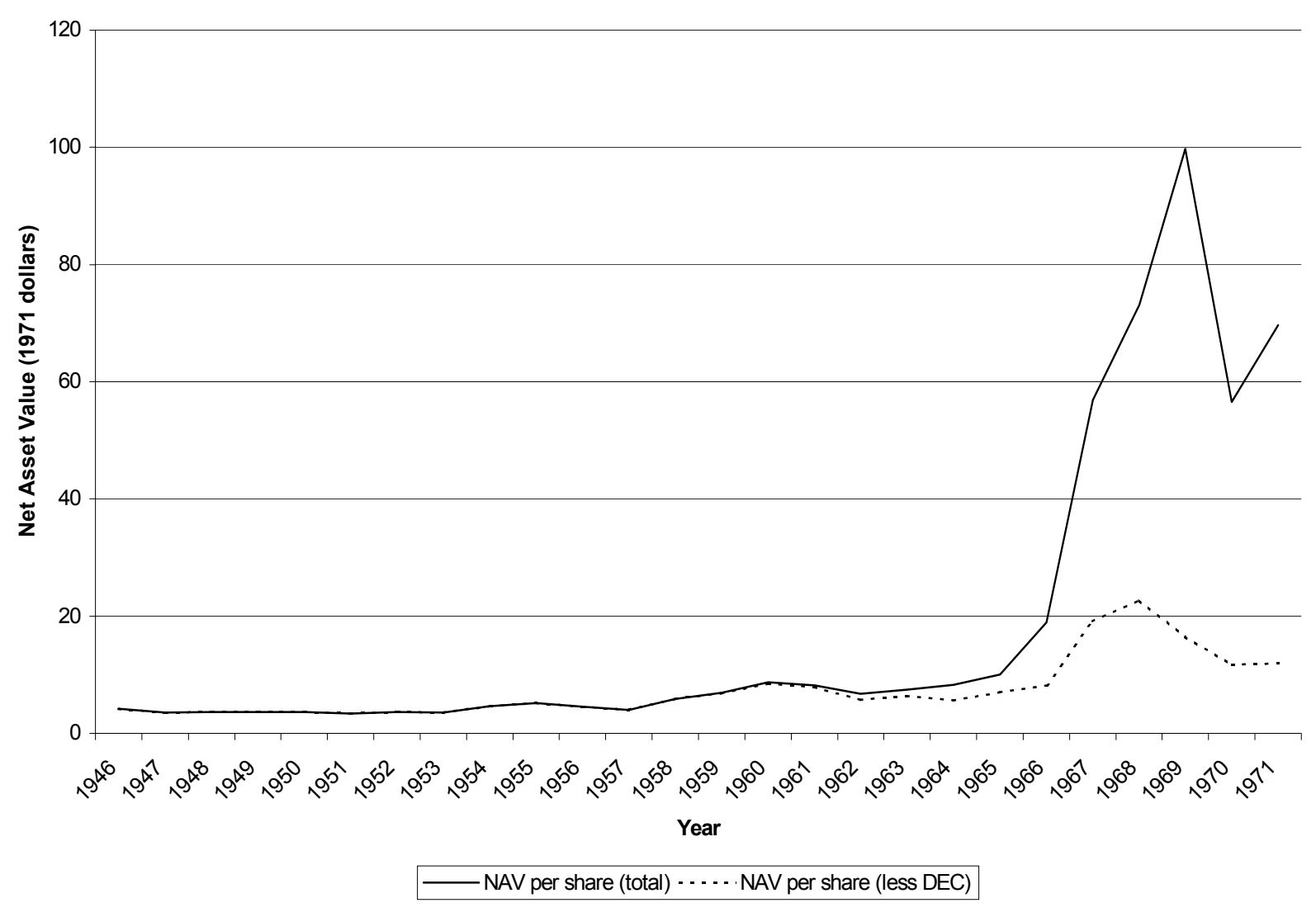


Figure 3: Outcomes of ARD Investments, 1946-73

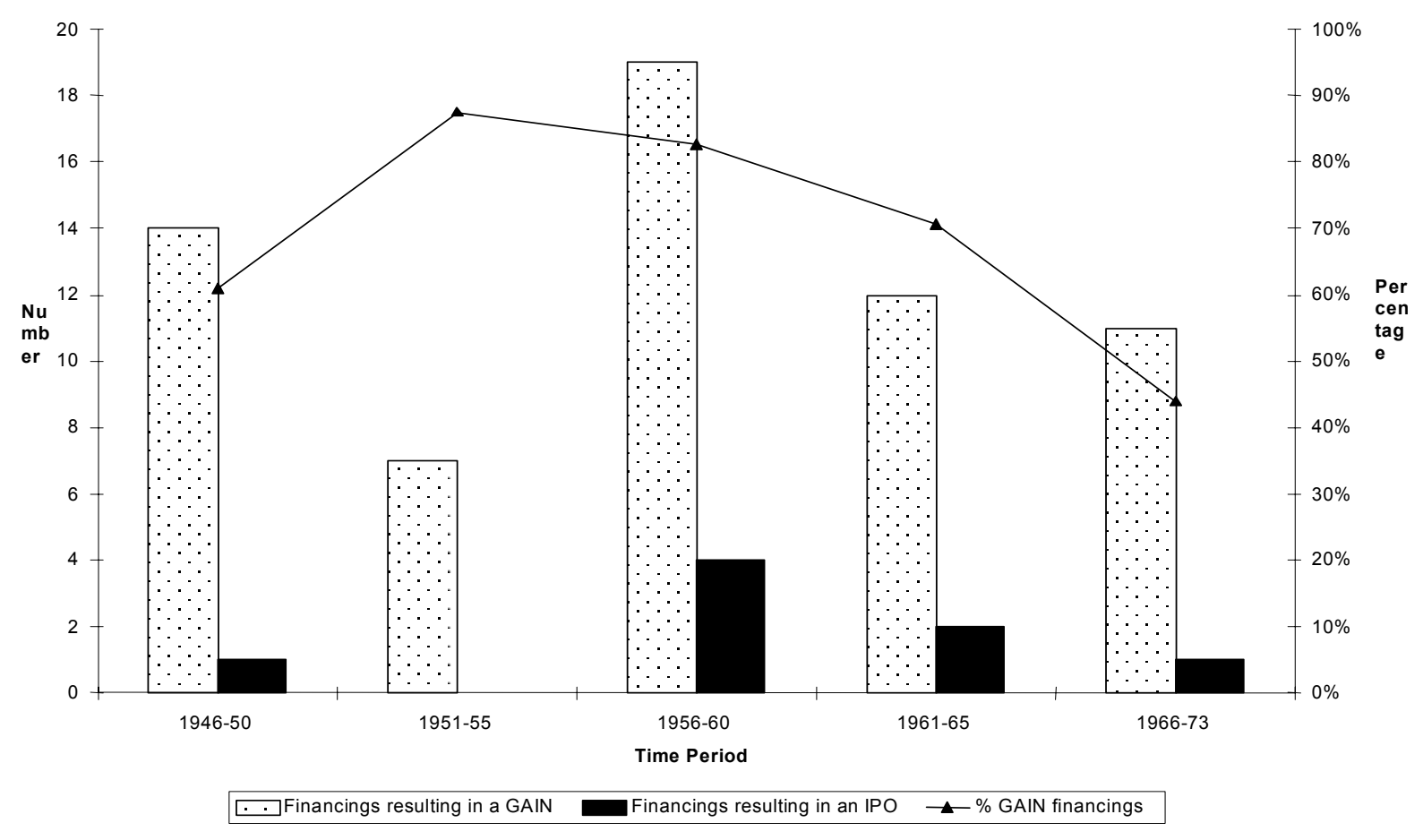

Source: American Research and Development corporate document (1972). 
Table 1: Institutional Investors in ARD in 1947

\begin{tabular}{|c|c|c|c|}
\hline Investor & $\begin{array}{c}\text { Type of } \\
\text { Organization }\end{array}$ & Location & $\begin{array}{c}\text { Total Investment by } \\
\text { Category and Firm } \\
(\$)\end{array}$ \\
\hline Investment Companies & & & $1,340,375$ \\
\hline Adams Express Company & $\begin{array}{l}\text { Closed end } \\
\text { investment trust }\end{array}$ & New York & \\
\hline $\begin{array}{l}\text { American International } \\
\text { Corp. }\end{array}$ & $\begin{array}{l}\text { Closed end } \\
\text { investment trust }\end{array}$ & New Jersey & 50,000 \\
\hline $\begin{array}{l}\text { Commonwealth } \\
\text { International Corp. }\end{array}$ & Mutual fund & Canada & \\
\hline $\begin{array}{l}\text { Consolidated Investment } \\
\text { Trust }\end{array}$ & $\begin{array}{l}\text { Closed end } \\
\text { investment trust }\end{array}$ & Boston & \\
\hline Investors Mutual Inc. & $\begin{array}{l}\text { Open end } \\
\text { investment trust }\end{array}$ & Minneapolis & 200,000 \\
\hline $\begin{array}{ll}\text { Massachusetts } & \text { Investors } \\
\text { Second Fund } & \\
\end{array}$ & $\begin{array}{l}\text { Open end } \\
\text { investment trust }\end{array}$ & Boston & 150,000 \\
\hline $\begin{array}{l}\text { Massachusetts Investors } \\
\text { Trust }\end{array}$ & $\begin{array}{l}\text { Open end } \\
\text { investment trust }\end{array}$ & Boston & 365,375 \\
\hline $\begin{array}{l}\text { North American Investment } \\
\text { Company }\end{array}$ & $\begin{array}{l}\text { Closed end } \\
\text { investment trust }\end{array}$ & San Francisco & \\
\hline Overseas Securities Co., Inc. & $\begin{array}{l}\text { Closed end } \\
\text { investment trust }\end{array}$ & New York & \\
\hline Insurance Firms & & & 300,000 \\
\hline $\begin{array}{l}\text { John Hancock Mutual Life } \\
\text { Insurance }\end{array}$ & Insurance company & Boston & 250,000 \\
\hline State Mutual Life Assurance & Insurance company & Worcester, MA & \\
\hline Educational Institutions & & & 225,000 \\
\hline MIT & University & Boston & 100,000 \\
\hline Rice Institute & University & Houston, TX & \\
\hline University of Pennsylvania & University & Philadelphia, PA & \\
\hline University of Rochester & University & Rochester, NY & \\
\hline Brokers and Companies & & & 281,625 \\
\hline Individuals & & & $1,610,500$ \\
\hline
\end{tabular}

Source: ARD (1946; 1947:3); Bullock (1959); Bogle 1951. 
Table 2

AMERICAN R\&D PORTFOLIO FIRM DEMOGRAPHICS

Projects and Financing Environment

\# of business projects evaluated

\# business projects funded

Projects funded/projects evaluated

Projects funded/financings from 1946-73

$\%$ financing in bear or recessionary market

Industrial Segment (\% of Investments)

Earth Sciences

Chemicals

Industrial Equipment

Scientific Instruments

Electronics

Data Processing \& Storage

Technology Publishing

Professional Services

Food Products

Education \& Media

Other or unknown

$\begin{array}{ll}\mathbf{1 9 4 6 - 5 0} & \mathbf{1 9 5 1 - 5 5} \\ & \\ 1869 & 739 \\ 26 & 14 \\ 1 \% & 2 \% \\ 22 \% & 12 \% \\ 58 \% & 7 \%\end{array}$

TIME PERIOD

1956-60 1961-65 $1966-73 \quad$ Total

688

28

$4 \%$

$23 \%$

$43 \%$

1050

22

$2 \%$

$18 \%$

$18 \%$

2538

30

$1 \%$

$25 \%$

$57 \%$

6884

120

$2 \%$

$100 \%$

$41 \%$

$\begin{array}{ll}4 \% & 21 \% \\ 35 \% & 7 \% \\ 31 \% & 14 \% \\ 8 \% & 14 \% \\ 4 \% & 0 \% \\ 0 \% & 21 \% \\ 0 \% & 0 \% \\ 0 \% & 14 \% \\ 12 \% & 0 \% \\ 0 \% & 0 \% \\ 8 \% & 7 \%\end{array}$

$7 \%$
$4 \%$
$14 \%$
$21 \%$
$25 \%$
$11 \%$
$4 \%$
$4 \%$
$0 \%$
$4 \%$
$7 \%$

\section{$5 \%$}

$9 \%$

$14 \%$

$18 \%$

$18 \%$

$9 \%$

$5 \%$

$14 \%$

$0 \%$

$0 \%$

$9 \%$

$\begin{array}{ll}0 \% & 6 \% \\ 10 \% & 13 \% \\ 7 \% & 16 \% \\ 17 \% & 16 \% \\ 17 \% & 14 \% \\ 3 \% & 8 \% \\ 3 \% & 3 \% \\ 7 \% & 7 \% \\ 3 \% & 3 \% \\ 17 \% & 5 \% \\ 16 \% & 10 \%\end{array}$


TABLE 3

VARIABLES, DEFINITIONS AND DESCRIPTIVE STATISTICS

\begin{tabular}{|c|c|c|c|c|c|c|c|c|}
\hline \multirow{2}{*}{ VARIABLE } & \multirow[b]{2}{*}{ DEFINITION } & \multicolumn{2}{|c|}{$\begin{array}{l}\text { FULL SAMPLE } \\
(1946-1973)\end{array}$} & \multicolumn{2}{|c|}{$\begin{array}{l}\text { FIRST HALF } \\
(1946-1960)\end{array}$} & \multicolumn{2}{|c|}{$\begin{array}{l}\text { SECOND HALF } \\
(1961-1973)\end{array}$} & \multirow[b]{2}{*}{ SOURCE } \\
\hline & & MEAN & $S D$ & MEAN & $S D$ & MEAN & $S D$ & \\
\hline $\begin{array}{l}\text { ARD } \\
\text { SOURCED }\end{array}$ & $\begin{array}{l}\text { Dummy }=1 \text { if ARD sourced the investment } \\
\text { through its network of contacts }\end{array}$ & 0.233 & 0.425 & 0.265 & 0.444 & 0.192 & 0.398 & $\begin{array}{l}\text { Doriot } \\
\text { Papers }\end{array}$ \\
\hline $\begin{array}{l}\text { INVESTED } \\
\text { EARLY* }\end{array}$ & $\begin{array}{l}\text { Dummy }=1 \text { if ARD created or invested early } \\
\text { in the portfolio company }\end{array}$ & 0.349 & 0.482 & 0.206 & 0.407 & 0.571 & 0.500 & $\begin{array}{l}\text { Doriot } \\
\text { Papers; } \\
\text { Interviews }\end{array}$ \\
\hline $\begin{array}{l}\text { R\&D } \\
\text { INTENSIVE* }\end{array}$ & $\begin{array}{l}\text { Dummy }=1 \text { if portfolio company was in one } \\
\text { of the following industries: earth sciences, } \\
\text { chemicals, industrial \& scientific equipment, } \\
\text { electronics, or data processing/storage }\end{array}$ & 0.733 & 0.444 & 0.809 & 0.396 & 0.635 & 0.486 & $\begin{array}{l}\text { ARD } \\
\text { Annual } \\
\text { Reports }\end{array}$ \\
\hline $\begin{array}{l}\text { MASS. } \\
\text { LOCATION* }\end{array}$ & $\begin{array}{l}\text { Dummy }=1 \text { if the portfolio company was } \\
\text { located in Massachusetts }\end{array}$ & 0.275 & 0.448 & 0.368 & 0.486 & 0.154 & 0.364 & $\begin{array}{l}\text { ARD Ann. } \\
\text { Reports }\end{array}$ \\
\hline $\begin{array}{l}\text { INVESTED } \\
\text { FIRST HALF }\end{array}$ & $\begin{array}{l}\text { Dummy }=1 \text { if ARD invested in the portfolio } \\
\text { company between } 1946-1960\end{array}$ & 0.566 & 0.498 & N/A & $\mathrm{N} / \mathrm{A}$ & $\mathrm{N} / \mathrm{A}$ & N/A & $\begin{array}{l}\text { ARD Ann. } \\
\text { Reports }\end{array}$ \\
\hline EQUITY ONLY & $\begin{array}{l}\text { Dummy }=1 \text { if ARD financed the portfolio } \\
\text { company through equity only }\end{array}$ & 0.342 & 0.476 & 0.368 & 0.486 & 0.308 & 0.466 & $\begin{array}{l}\text { ARD Ann. } \\
\text { Reports }\end{array}$ \\
\hline DEBT ONLY & $\begin{array}{l}\text { Dummy }=1 \text { if ARD financed the portfolio } \\
\text { company through debt only }\end{array}$ & 0.150 & 0.359 & 0.147 & 0.356 & 0.154 & 0.364 & $\begin{array}{l}\text { ARD Ann. } \\
\text { Reports }\end{array}$ \\
\hline GAIN* & $\begin{array}{l}\text { Dummy }=1 \text { if liquidation of the portfolio } \\
\text { company resulted in a gain }\end{array}$ & 0.646 & 0.481 & 0.741 & 0.442 & 0.533 & 0.505 & $\begin{array}{l}\text { Doriot; } \\
\text { Interviews }\end{array}$ \\
\hline
\end{tabular}

* indicates t-test of difference of means between the (1946-60) and (1961-1973) time periods is significant at a minimum of the 5\% level 
TABLE 4

ARD "PERFORMANCE" PROBITS

\begin{tabular}{|c|c|c|c|c|}
\hline & \multicolumn{4}{|c|}{$\begin{array}{c}\text { Dependent Variable = } \\
\operatorname{Pr}(\text { GAIN) } \\
N=99 \text { observations }\end{array}$} \\
\hline & $\begin{array}{c}\text { (4-1) } \\
\text { bivariate } \\
\text { correlation }\end{array}$ & $\begin{array}{l}\text { (4-2) } \\
\text { five year time } \\
\text { dummies }\end{array}$ & $\begin{array}{c}\text { (4-3) } \\
(4-1) \text { with } \\
(4-2)\end{array}$ & $\begin{array}{c}\text { (4-4) } \\
\text { (4-3) with } \\
\text { controls for stage } \\
\text { and location } \\
\text { effects }\end{array}$ \\
\hline \begin{tabular}{|l} 
R\&D \\
INTENSIVE
\end{tabular} & $\begin{array}{c}0.595 \\
(0.287)\end{array}$ & & $\begin{array}{c}0.655 \\
(0.315)\end{array}$ & $\begin{array}{c}0.621 \\
(0.339)\end{array}$ \\
\hline INVESTED EARLY & & & & $\begin{array}{c}0.315 \\
(0.356) \\
\end{array}$ \\
\hline \begin{tabular}{|l} 
MASS. \\
LOCATED
\end{tabular} & & & & $\begin{array}{c}0.675 \\
(0.395)\end{array}$ \\
\hline \begin{tabular}{|l|} 
ARD \\
SOURCED
\end{tabular} & & & & $\begin{array}{l}-0.298 \\
(0.400)\end{array}$ \\
\hline \begin{tabular}{|l|} 
ARD INVESTED \\
$1946-1950$ \\
\end{tabular} & & $\begin{array}{c}0.456 \\
(0.356) \\
\end{array}$ & $\begin{array}{c}0.296 \\
(0.371)\end{array}$ & $\begin{array}{c}0.257 \\
(0.433) \\
\end{array}$ \\
\hline \begin{tabular}{|l|} 
ARD INVESTED \\
$1951-1955$
\end{tabular} & & $\begin{array}{c}1.330 \\
(0.616)\end{array}$ & $\begin{array}{c}1.499 \\
(0.651)\end{array}$ & $\begin{array}{c}1.520 \\
(0.684)\end{array}$ \\
\hline \begin{tabular}{|l|} 
ARD INVESTED \\
$1956-1960$ \\
\end{tabular} & & $\begin{array}{c}1.119 \\
(0.389)\end{array}$ & $\begin{array}{c}1.053 \\
(0.398)\end{array}$ & $\begin{array}{l}1.139 \\
(0.451)\end{array}$ \\
\hline \begin{tabular}{|l|} 
ARD INVESTED \\
$1961-1965$
\end{tabular} & & $\begin{array}{c}0.721 \\
(0.400)\end{array}$ & $\begin{array}{c}0.633 \\
(0.403)\end{array}$ & $\begin{array}{c}0.596 \\
(0.413)\end{array}$ \\
\hline CONSTANT & $\begin{array}{l}-0.046 \\
(0.241) \\
\end{array}$ & $\begin{array}{l}-0.180 \\
(0.238) \\
\end{array}$ & $\begin{array}{l}-0.585 \\
(0.312)\end{array}$ & $\begin{array}{l}-0.742 \\
(0.366) \\
\end{array}$ \\
\hline LL & -62.158 & -58.456 & -56.258 & -52.732 \\
\hline
\end{tabular}


TABLE 5

ARD FINANCING METHOD

MULTINOMIAL LOGITS

\begin{tabular}{|c|c|c|c|c|}
\hline & \multicolumn{4}{|c|}{$\begin{array}{c}\text { Dependent Variable = DEBT-ONLY or EQUITY-ONLY } \\
(\text { DEFAULT = DEBT \& EQUITY) }\end{array}$} \\
\hline & \multicolumn{2}{|c|}{$\begin{array}{c}\text { FIRST HALF } \\
(1946-1960) \\
N=\mathbf{6 8} \text { observations }\end{array}$} & \multicolumn{2}{|c|}{$\begin{array}{c}\text { SECOND HALF } \\
(1961-1973) \\
N=\mathbf{4 9} \text { observations }\end{array}$} \\
\hline & \multicolumn{2}{|c|}{$(5-1)$} & \multicolumn{2}{|c|}{$(5-2)$} \\
\hline & $\begin{array}{l}\text { DEBT-ONLY } \\
=1\end{array}$ & $\begin{array}{l}\text { EQUITY- } \\
\text { ONLY = } 1\end{array}$ & $\begin{array}{l}\text { DEBT-ONLY } \\
\quad=1\end{array}$ & $\begin{array}{l}\text { EQUITY- } \\
\text { ONLY }=1\end{array}$ \\
\hline \begin{tabular}{|l} 
R\&D \\
INTENSIVE
\end{tabular} & $\begin{array}{l}-2.179 \\
(1.094)\end{array}$ & $\begin{array}{l}-0.671 \\
(0.742)\end{array}$ & $\begin{array}{c}0.566 \\
(0.949)\end{array}$ & $\begin{array}{l}-0.231 \\
(0.724)\end{array}$ \\
\hline $\begin{array}{l}\text { ARD INVESTED } \\
\text { EARLY }\end{array}$ & $\begin{array}{c}0.896 \\
(1.025)\end{array}$ & $\begin{array}{c}0.540 \\
(0.739)\end{array}$ & $\begin{array}{l}1.080 \\
(0.928)\end{array}$ & $\begin{array}{c}0.160 \\
(0.717)\end{array}$ \\
\hline $\begin{array}{l}\text { MASSACHUSETTS } \\
\text { LOCATED }\end{array}$ & $\begin{array}{c}0.460 \\
(0.859)\end{array}$ & $\begin{array}{c}0.246 \\
(0.608)\end{array}$ & $\begin{array}{l}-0.004 \\
(3.610)\end{array}$ & $\begin{array}{l}1.744 \\
(1.175)\end{array}$ \\
\hline \begin{tabular}{|l|} 
ARD \\
SOURCED
\end{tabular} & $\begin{array}{c}2.066 \\
(0.976)\end{array}$ & $\begin{array}{c}0.601 \\
(0.671)\end{array}$ & $\begin{array}{l}-0.555 \\
(1.234)\end{array}$ & $\begin{array}{l}-2.695 \\
(1.499)\end{array}$ \\
\hline CONSTANT & $\begin{array}{l}-0.619 \\
(0.763)\end{array}$ & $\begin{array}{l}-0.053 \\
(0.647)\end{array}$ & $\begin{array}{l}-1.957 \\
(1.033)\end{array}$ & $\begin{array}{l}-0.322 \\
(0.640)\end{array}$ \\
\hline Log Likelihood & \multicolumn{2}{|c|}{-63.509} & \multicolumn{2}{|c|}{-43.531} \\
\hline
\end{tabular}

